\title{
The knowledge gap: Implications of leveling the playing field for low-income and middle-income children
}

\author{
SUSAN B. NEUMAN \\ University of Michigan, Ann Arbor, USA \\ DONNA CELANO \\ Chestnut Hill College, Philadelphia, Pennsylvania, USA
}

n 1996, the city of Philadelphia, supported by a US $\$ 20$ million gift from the William Penn Foundation, began a five-year project to transform 32 neighborhood branch libraries into a technologically modern urban library system. The project's goal was to enhance access to print and technology for all children and families in Philadelphia, focusing specifically on improving the lives of disadvantaged children and closing the achievement gap. Rooted in the belief that institutions can serve as key leverage points for stimulating social change, the creation of the Model Urban Library Program was designed as a comprehensive community-based initiative (CCBI). These initiatives focus on the environmental origins of social problems (Halpern, 1994), the recognition that geographically bounded areas have essentially isolated the poor, causing and often perpetuating poverty and social inequality (Wilson, 1987). Consequently, by equalizing access to reading resources, the Foundation sought to "level the playing field" across different income groups to promote reading improvement particularly for those children from economically distressed neighborhoods.

"Leveling the playing field" represents a theory of action that underlies much of public policy (Cross, 2004). It argues that equalizing resources (funding) has a causal effect on equalizing opportunity. Title I funds, for example, the cornerstone of federal aid to U.S. elementary and secondary schools, distribute financial resources to school districts to compensate for poverty and disadvantage, requiring 
This study examines children's uses of reading resources in neighborhood public libraries that have been transformed to "level the playing field." Through Foundation funding (US\$20 million), the public library system of Philadelphia converted neighborhood branch libraries into a technologized modern urban library system, hoping to improve the lives of disadvantaged children and their families by closing the achievement gap. Using a mosaic of ethnographic methodologies, four studies examined children's uses of library resources in low-income and middleincome neighborhood libraries, prior to renovations and technology, right after, and once the novelty had worn off a year later, for preschoolers, elementary, and teens. Results indicated that despite heavy library use across lowincome and middle-income children, quality differentials in the way resources were used appeared at all age levels, prior to, immediately after, and stronger still following technology renovations. Taken together, these studies suggest equal resources to economically unequal groups did not level the playing field. Instead, it appeared to widen the knowledge gap between low-income and middle-income children.

Este estudio examina el uso que hacen los niños de los recursos de lectura en bibliotecas públicas barriales que han sido transformadas para "nivelar el campo de juego". Por medio de un subsidio (20 millones de dólares), el sistema de bibliotecas públicas de Filadelfia convirtió las bibliotecas barriales en un sistema de bibliotecas moderno, urbano y con tecnología, esperando mejorar la vida de los niños en desventaja y sus familias, así como cerrar la brecha entre los logros de los niños de clase media y baja. Mediante un mosaico de metodologías etnográficas, cuatro estudios examinaron el uso que hacían los niños de los recursos de las bibliotecas en los barrios de clase baja y media en tres momentos: antes de las renovaciones y la tecnología, inmediatamente después y cuando habían dejado ya de ser novedad, un año más tarde para los niños de nivel inicial, primario y adolescentes. Los resultados indicaron que, a pesar de registrarse un uso intenso tanto en los niños de clase baja como en los de clase media, aparecieron diferencias cualitativas en la forma en que los recursos fueron usados en todas las edades, antes, inmediatamente después y, más fuertemente, luego de las renovaciones tecnológicas. En conjunto, estos estudios sugieren que iguales recursos a grupos económicamente diferentes no nivelaron el campo de juego. Al contrario, la brecha de conocimientos entre los niños de clase baja y clase media pareció agrandarse.

Diese Studie untersucht die Nutzung der Leseressourcen von Kindern in öffentlichen Nachbarschaftsbüchereien, die zum „Angleichen der Spielregeln“ umgewandelt wurden. Durch Spendenaufbringung (20 Millionen Dollars) veränderte Philadelphias öffentliches Büchereisystem Büchereiniederlassungen in Nachbarschaften in ein technologisch modernes städtisches Büchereisystem, in der Hoffnung, das Leben von benachteiligten Kindern und ihrer Familien durch Schließen des Leistungsabstands zu verbessern. Durch Anwendung eines Mosaiks von ethnographischen Methodologien untersuchten vier Studien die Nutzung der Büchereiressourcen durch Kinder von Büchereien in Nachbarschaften mit niedrigen und mittleren Einkommen vor Renovierungen und Technologie, unmittelbar danach, und nachdem die Erneuerungsbegeisterung nachließ, ein Jahr danach für Vorschüler, Grundschüler und Teens. Ergebnisse zeigten, daß trotz starker Büchereinutzung von Kindern quer durch niedrige und mittlere Einkommen Qualitätsunterschiede entstanden in der Art wie die Ressourcen durch alle Altersgruppen, vorher, unmittelbar danach, und stärker noch als Folge der Technologieerneuerung verwandt wurden. Zusammengefasst, deutet diese Studie an, daß gleiche Ressourcen für wirtschaftlich ungleiche Gruppen nicht die Spielregeln ausglichen. Stattdessen, so schien es, erweiterte sich die Wissenslücke zwischen Kindern aus niedrigen Einkommen und mittleren Einkommen.

\section{ABSTRACTS}

The knowledge gap: Implications of leveling the playing field for low-income and middle-income children

\section{La brecha en el conocimiento: Consecuencias de nivelar el campo de juego para niños de clase baja y clase media}

Die Wissenslücke:
Auswirkungen
beim Angleichen
der Spielregeln für
Kinder niedrigen
und mittleren
Einkommens


Les écarts de connaissance : implications du nivellement du terrain de jeu pour les enfants de milieu défavorisé et de classe moyenne
知識の满 : 低所得及び中所得家庭の子供達の競技場を一様にすることの示唆

本研究は、『競技場を一様に』と変えられた近くにある公立図書館における了供達によるリ ーディング・リソースの利用について䛇ぐた。（2000万ドルの）财団基金によって、フ ィラデルフィアの公立図書館システムは、学力の溝を索埋めることによって㤩まれていない了. 供達とその家族の尘活の改善を願い、近くの図書館の分館を高度技術化された、近代的な都 市図書館に変えた。複数の民族学的方法を組み命わせて用い、4つの研究で、低所得及び中 所得の地域の図書館における了.供達の図書館のリソースの利用を、改革とテクノロジー前、 直後、そして、月新しさがなくなってから、一年後、就学前の了.供達、小学訨、1 0 代の了. 供達に関して媩へたた。結果、図書館の利用は、低所得家庭と中所得家庭の了供達の閒で頻繁 であったものの、リソースの使い方の質的差は、すべての年齢層でテクノロジー改革前、直 後に先られ、その後は、さらに大きくなった。これらの研究結果を合わせてみると、経済的 に異なるグループに同じリソースを与えても、競技場は同じレベルにならないということが 示峻される。むしる、家庭が低所得の了・供達と中所得の了-供達の閒の知識の满を広げてしま うようであった。

Cette étude étudie l'utilisation que font les enfants des ressources en lecture de bibliothèques publiques de proximité qui ont été transformées afin de "niveler le terrain de jeu ". Grâce à un financement de fondation (20 millions de dollars), le système de la bibliothèque publique de Philadelphie a transformé le réseau des bibiliothèques de proximité en un système de bibliothèque urbaine moderne technologique, avec l'espoir d'améliorer la vie des enfants de milieu défavorisé et de leurs familles en comblant les écarts de réussite. En utilisant toute une mosaïque de méthodologies ethnographiques, quatre études ont étudié comment les enfants ont utilisé les ressources des bibliothèques dans des bibliothèques de proximité de milieu défavorisé et de milieu moyen, avant les rénovations et la technologie, juste après, et une fois la nouveauté dissipée, un an plus tard, avec des enfants d'école maternelle, élémentaire, et secondaire. Les résultats montrent qu'en dépit d'une importante utilisation des bibliothèques par les enfants de milieu défavorisé et de classe moyenne, il apparaît des différences qualitatives à tous les âges dans la façon dont les ressources sont utilisées, avant, imédiatement après, et encore plus fortement après les rénovations technologiques. De manière générale, ces études suggèrent que des ressources égales fournies à des populations économiquement inégales ne nivellent pas le terrain de jeu. Mieux encore, il semble que les écarts de connaissance entre les enfants de milieu défavorisé et de classe moyenne se soient encore élargis.

\section{Ровную площадку - каждому: роль доступных ресурсов в академических успехах детей из семей с низким и средним доходом}

Исследование посвянено тому, как дети пользуются ресурсами местных публичных библиотек, принявших участие в программе “Ровную плопадку - кажАому”. БАагодаря полученному финансированию (20 миллионов долларов), публичные библиотеки Филадельфии и ее пригородов были преобразованы в высоко технологичную, современную библиотечную систему - в частности, Аля того, чтобы Аети из семей с низким Аостатком имели равные со сверстниками возможности и смогАи Аобиться не меньших успехов в учебе. Используя целый ряд эгнографических методик, авторы провели четыре исследования в районах компактного проживания семей со среАним и низким Аоходом, сравнивая, как дошкольники, младшие школьники и поАростки пользовались библиотечными ресурсами Ао и сразу после реконструкции и переоснашения библиотек, а также год спустя, когАа притупилось опушение новизны. Результаты показали, что - несмотря на активное пользование библиотечными ресурсами всеми детьми (как из семей со средним, так и с низким АохоАом) - качественные параметры использования этих ресурсов сильно разнились во всех возрастных группах на кажАом этапе исследования, то есть Ао, сразу после и, особенно, по прошествии года после реконструкции библиотек. В совокупности эти исслеАования показывают, что одинаковые ресурсы, имеющиеся в распоряжении экономически неравных групп, не "выравнивают плоцадку" Аля кажАого. Как выяснилось, разАичия в академических Аостижениях этих Аетей Ааже усугубились. 
states to document comparability in spending across Title I and non-Title I schools (Cowan \& Manasevit, 2002). Starting with the Great Society programs of the 1960s, the complex formulas designed to create comparability have been based on the prevailing belief that the major shortcomings of programs in highpoverty areas involve the lack of funding (Cross), not lack of knowledge about better ways to educate economically disadvantaged children.

Despite its wide and continuing application in policy, however, the causal connection between equal funding and equal opportunity has been subject to great dispute. Coleman's congressionally mandated report of educational inequity (Coleman et al., 1966), for example, found that variation in resources had little-almost nothing - to do with achievement inequity. Instead, he argued that family characteristics and socioeconomic status contributed more to learning than the schools actually did. Although subsequent analyses using more sophisticated analytic techniques have seriously challenged this finding (Bryk \& Raudenbush, 1991), researchers and policymakers (Burtless, 1996; Welch, 2001) continue to argue the benefits of "leveling the playing field" for creating equal opportunity for low-income children.

Recent policy analysts (Carey, 2003; Rothstein, 2004), however, have suggested an alternative argument. Instead of posing the question as either/or, these analysts have argued that a more accurate approach should be bothland. Given the powerful influences of social-class characteristics on achievement factors, financial resources may be important, but insufficient for leveling the playing field. Instead, they argue that a more reasonable approach would be to provide additional resources above and beyond comparability, specifically targeted to the needs of lowincome children. That is, once we level the playing field by providing comparable resources, we might need to keep on going and tip the balance toward providing more resources to low-income children who need them.

This study provides a unique opportunity to analyze "leveling the playing field" as a theory of action. It examines children's uses of reading resources not in schools, but in neighborhood public libraries. Over six years, we witnessed the transformation of 32 branch libraries in low- to high-income neighborhoods throughout the city. Although we recognized that direct causal analyses would not be possible due to the many uncontrolled variables, we sought evidence to determine if these new resources were serving an enhanced educational function and providing better literacy opportunities and outcomes for lowincome children. Conceptualizing our study as a se- ries of targeted, theoretically driven inquiries, we focused on how, why, and for what purposes libraries were used in different communities, conducting naturalistic studies of reading-related activity (15 in all). In this analysis, we report on four of these studies, designed to examine the transformative influence of technologizing libraries for leveling the playing field. Specifically, we asked these questions: Does equal access to resources for children in low- and middleincome neighborhoods equalize opportunity? Or might it be necessary to tip the scale toward providing additional targeted resources to low-income children?

\section{Examining the causal connections between income and achievement: The theory of action}

Achievement differences among poor and minority children compared to their middle-class counterparts have deep roots (Barton, 2003); they tend to arrive early and stay late. Even before formal schooling begins, the ravages of poverty have shown their influence (Denton, West, \& Waltston, 2003;

Duncan \& Brooks-Gunn, 1997): Children in lowincome families lag significantly behind their more affluent peers academically, socially, and physically (National Assessment of Educational Progress [NAEP], 2004; Rothstein, 2004). In a recent analysis of the Early Childhood Longitudinal StudyKindergarten cohort (ECLS-K), for example, Lee and Burkam (2002) reported that the average cognitive scores of children at age 4 in the highest socioeconomic status (SES) groups were $60 \%$ above the scores of the lowest SES children. Based on previous studies, this initial gap is likely to continue or may actually increase throughout children's schooling (Juel, Griffith, \& Gough, 1986). The recent National Assessment of Educational Progress reports that economically advantaged children score at or above the basic level of reading at nearly twice the rate compared to those who are disadvantaged. Lower achieving children who are often poor and members of minority groups face greater challenges in comprehending materials and are at greater risk of falling behind and dropping out.

But the very consistency of this high correlation between poverty and achievement strongly suggests that something other than innate ability must be determining these results. Economists and policymakers (Duncan \& Brooks-Gunn, 1997; Mayer, 1997) argued that it is the concomitants related to 
poverty and not poverty itself that takes such a toll on children's cognitive processes. Specifically for reading achievement, authorities (Duncan $\&$ Brooks-Gunn; Foster, 2002) have speculated that the influence of poverty may occur through two major pathways: material resources and psychological resources.

The first pathway by which poverty affects children is through its impact on the family's ability to invest in resources related to children's development (Foster, 2002). Income enables families to purchase books, lessons, and stimulating learning materials that engage children in learning about reading and about their worlds. Although little is known about the importance of developmental timing of economic deprivation during early childhood, evidence suggests that these early experiences with print (Bus, van IJzendoorn, \& Pellegrini, 1995; Teale \& Sulzby, 1986; Wells, 1985) are influential in learning to read. Yet despite their eagerness for print resources, poor families often lack disposable income to afford them (Neuman, Celano, Greco, \& Shue, 2001). In addition, resources may be unavailable in their neighborhoods. For example, in our analysis of four neighborhoods in Philadelphia, we found striking disparities in access to print resources for children who lived in low- or middle-income communities (Neuman \& Celano, 2001). Compared with 13 book titles available per child in the middle-income neighborhoods, only 1 book title was available for every 300 children in the poor communities. Inequity was reported in the number of resources, choice and quality of these resources, and amount and quality of literacy materials in their public schools and public libraries in the community.

With limited access to print materials and opportunities for learning, a second pathway may be significantly curtailed. This pathway relates to the quality of the home environment and mother-child interactions over stimulating activities and learning opportunities (Duncan \& Brooks-Gunn, 1997). Without opportunities to be read to, children have less experience with new, different, and more sophisticated vocabulary outside of their day-to-day encounters (Hart \& Risley, 2003); they are less likely to learn about their world and to hear decontextualized language, the beginnings of abstracting information from print. And, as Walberg and Tsai (1983) and Stanovich (1986) in their now classic model of the Matthew Effect posited, differences in cognitive, motivational, and educational experiences in the early years become magnified in the process of reading acquisition. Children who develop efficient decoding processes early on are likely to be able to concentrate on the meaning of the text. They will read more, practice, and get better at it, thus enjoying the further riches of reading. Unfortunately, in a contrasting trajectory, children who do not become proficient in these skills begin a negative spiral of cumulative disadvantage. Once in public schools, the problem often becomes further aggravated by remedial instruction that exposes less skilled children to fewer interactions with text than their more skilled peers (Allington, 1983), ultimately providing less skilled students with the poorest language and literacy instruction. Such unrewarding experiences in reading multiply, with the consequences that children attend less to the comprehensibility of reading, its purpose, and potential usefulness.

A subsequent gap may occur, perhaps even more insidious. As formulated by communication scholars Tichenor, Donohue, and Olien (1970), differences in the amount, rate, and speed of gathering information from media sources lead to a growing knowledge gap. The "knowledge gap" refers to the differentials in information acquired and retained by individuals. If we assume that knowledge produces more knowledge (Bransford, Brown, \& Cocking, 2000; Donovan \& Bransford, 2005), those who have access to information read more, engage more in higher level conversations, learn more, and use information for fulfilling specific purposes and needs. Greater use enhances speed of information acquisition, which over time is likely to accelerate a knowledge gap between those who have access and those who do not. More than 90 studies (Gaziano, 1997) ranging from public affairs to health knowledge have demonstrated the persistence of knowledge inequalities across topics and research settings. Even more than achievement differences, the knowledge gap is associated with quality-of-life differences as varied as disease and crime prevention and health-related problems.

Therefore, striking differences in material resources and the quality of the home environment, as expressed by parents' interactions, begin to define what children are taught and what is modeled and reinforced in these early years, just when cognitive connections are forming. And these differences are thought to account for the social stratification of knowledge and achievement that we see evidenced in the gap between low-income and middle- to higher income children.

Leveling the playing field or equalizing resources according to the theory of action that underlies many policies for low-income children and early childhood programs (e.g., Title I; Head Start) is assumed to compensate for the material resources that are lacking in economically disadvantaged neighbor- 
hoods and homes, and the subsequent instructional resources that involve children in the critical skills associated with reading success. But the question we raise in this study is whether equal resources to children of differential socioeconomic circumstances can truly equalize opportunity.

\section{Methodological strategy}

We approached the analysis of the Model Urban Library initiative in Philadelphia as a theorybased evaluation with an overarching question: What was the effect of a comprehensive communitybased initiative that focused on equalizing funding and resources across neighborhood libraries on closing the gap for children from disadvantaged neighborhoods? Although recognizing the necessity of evaluating comprehensive community-based initiatives and the potential lessons that can be learned and applied to the next generation of policies, programs, and research, such initiatives have been especially challenging for evaluators. They rely on the purposeful application of knowledge in practice, are firmly rooted in the community, and contextually dependent (Kubisch, Weiss, Schorr, \& Connell, 1995). Establishing a special roundtable of scholars to examine evaluation strategies for such large-scale initiatives, the National Academies of Sciences group (Connell, Kubisch, Schorr, \& Weiss, 1995) concluded that although prevailing evaluation approaches such as randomized comparison groups may be akin to the "nector of the gods" (p. 12), alternative approaches were required to examine these initiatives.

Researchers (Hollister \& Hill, 1995; Weiss, 1995) examining these initiatives have argued for theory-based evaluations. Such approaches represent a far cry from the horse-race mentality, or atheoretical approach often ascribed to evaluation research (Reinking \& Alvermann, 2005). Rather, this approach bases evaluation on theories of change both explicit and/or implicit that may underlie the initiative. In theory-based evaluations, measures are developed that may be imperfect but provide useful feedback to track the unfolding of these assumptions, examining the extent to which the theory holds. Such strategies might include documenting progress, measuring inputs, focus groups, and a variety of contextual indicators. In the absence of a comparison control group, Hollister and Hill (1995) recommended establishing a counterfactual, comparing communities to assess the experiences of innovations for different groups, using contextually oriented indicators. Taken together, the aim is to provide a textured picture of what is happening in the community, its implications for understanding human behavior, and important directions for further research and broad policy directions.

Taking an ecological perspective, then, we developed a series of studies to examine how these environments influenced individual behaviors and, in turn, how individuals influenced the environment, recognizing the reciprocal tensions that change both settings and individuals over time. Examining environment typologically as a nested arrangement of structures and systems of interactions

(Bronfenbrenner, 1979), we conducted studies that looked at the broader context of activities, such as access to resources in neighborhoods (Neuman \& Celano, 2001), to the context of the library, through detailed ethnographies involving frozen time-checks to determine hour-by-hour involvement in the libraries, and shadowings of personnel in libraries, to the specific interactions within the library with family, peers, the computer and reading materials. Each study was informed by the previous analyses, giving us a richly detailed understanding of activities and interactions not limited to a single setting, but beyond the immediate situation.

We learned throughout our set of inquiries that, as Dressman (1997) described, libraries are not primary spaces but optional ones that are visited rather than inhabited. As neighborhood settings, the library's mission is to support the virtues of reading, offering children opportunities to read what they choose, rather than what is chosen for them. Unlike school, the public library has no predetermined curriculum or pedagogical emphasis (Duran, 1993); rather, it is designed as neutral space available to all ages and socioeconomic status groups. Historically, therefore, public libraries have perceived themselves as society's safety net (Van Slyck, 1995), reducing inequity by making information readily accessible to the community at large. Common across contexts, they seek to consciously level the playing field, in contrast to other institutions, which MacLeod (1995) described as "reinforcing social inequality while pretending to do the opposite" (p. 12).

Our studies indicated a gradual but clear transformation over the six years of our analysis from public libraries as book-centered environments to modern urban libraries as information- and community-centered environments, embracing multiple technologies and books (Neuman, 2001a). And it is within this larger evaluation that we focused four targeted analyses examining how these neighborhood libraries, committed to open and equitable information for all, contributed toward closing the 
gap for children from highly distressed neighborhoods and their counterfactual middle-income neighborhoods.

\section{Setting and sample}

Starting in 1996, the Free Library of Philadelphia began a five-year process to renovate neighborhood branch libraries. Considered the heart of urban renewal, these branches were to include cutting-edge library services and technology, along with what was defined as a "wow" factor to encourage nontraditional patrons to come to the library. Integral to the plan were strategies to highlight the importance of reading and technology resources for enhancing educational and job-related opportunities in community life. Working with neighborhood groups, architects created distinctive designs to reflect each branch's local culture, heritage, and talents; librarians ordered special collections to match patrons' native language and cultural interests; and children's librarians and technology specialists provided special after-school programming for children.

Although each branch was designed to reflect its patrons' unique culture, renovations included a set of common new resources: (1) Eight computers in the teen/adult section, linked to the Internet. Before technology enhancements, libraries had provided only two menu-driven terminals with electronic catalogues and limited, text-based Internet capabilities for use by teens only. (2) One preschool computer (due to limitations in space), programmed with six learning games. (3) A dedicated preschool space. (4) A collection of 1,000 new books plus software programs for each library. In addition, libraries provided the following new services: (1) Training for all children's librarians on literacy development and information literacy practices. Over 150 hours of training were scheduled for librarians through the system to accommodate different work schedules. Training included sessions on collections for young children, teens, and adults; selection criteria for software; privacy issues; and management. (2) Technology specialists to provide additional assistance to children and family patrons new to technology (20 hours per week). (3) A policy of open shelving (making the library more attractive) and interfiling (filing adult and teen books together to enable adults to select books on the basis of their reading and comfort level). Each year, approximately six libraries closed down for renovation, providing us with an opportunity to examine library habits both before and after technology improvements.
Laying the foundation for further inquiries, our team of 10 urban ethnographers and a postdoctoral fellow first examined neighborhood access to print, that is, availability of books, newspapers, magazines, public places and spaces for reading, and school resources, such as computer labs and school libraries, in communities in the city. Our analysis reported stark and triangulated differences for the availability of print resources clearly along socioeconomic status levels; neighborhoods with concentrated pockets of poverty had few resources (even in their local schools); middle- and upper income neighborhoods had many and multiple resources. This analysis (Neuman \& Celano, 2001) became the basis for identifying a sample of neighborhood libraries from the larger population; four of the libraries were in high-print neighborhoods (with bookstores, signs, places and spaces for print activities, and school libraries available), four were in lowprint neighborhoods (no stores, graffiti-covered signs, no public places for reading, closed school libraries). (See Table 1.) All together, these neighborhood libraries represented census tracts for almost a quarter of a million children and families.

In addition to documenting gradual transformations in how children and families used library resources, our team began a series of targeted, systematic observational studies. We needed to press for evidence that the initiative was serving the objectives for which it had been funded. Rather than hypothesize differences, our project sought to build a theoretical understanding of how children in lowand middle-income neighborhoods with widely different access to resources outside of the library might use reading materials, how they might access new technology (computers in libraries in 1996 were still a relatively rare phenomenon), and how or if these patterns might change after the novelty effect wore off. Working together, we developed a focus question and constructed contextually based indicators (Weiss, 1995) to address the applied question. Randomly selecting two low-income and two middleincome libraries for each individual study, we attempted not to overburden library staff or to be too intrusive in any setting throughout the study period. Table 2 provides a summary of the projects, with collection phases and types of records collected.

Research assistants of ethnic status similar to patrons in the neighborhood were assigned to each library setting. These research assistants were doctoral students from the urban ethnography program at Temple University, and well-versed in multimethod fieldwork techniques (Goetz \& LeCompte, 1984) including situated listening, observation, interview- 
TABLE 1

DEMOGRAPHICS OF LIBRARIES

\begin{tabular}{|c|c|c|c|c|c|c|c|}
\hline \multirow{2}{*}{$\begin{array}{l}\text { Neighborhood } \\
\text { Falls of Schuylkill }\end{array}$} & \multirow{2}{*}{$\frac{\text { Total population }}{10,099}$} & \multirow{2}{*}{$\frac{\text { Juvenile population }}{1,130}$} & \multicolumn{2}{|c|}{ Percentage ethnicity } & \multirow{2}{*}{$\frac{\text { Percentage poverty }}{6}$} & \multicolumn{2}{|c|}{$\begin{array}{l}\text { Percentage } \\
\text { educational attainment }\end{array}$} \\
\hline & & & $\begin{array}{l}\text { Caucasian } \\
\text { African American } \\
\text { Asian } \\
\text { Hispanic } \\
\text { Other }\end{array}$ & $\begin{array}{r}72 \\
2 \\
10 \\
3 \\
13\end{array}$ & & $\begin{array}{l}\text { Below } 12 \text { th grade } \\
\text { High school graduate } \\
\text { Some college } \\
\text { Graduate }\end{array}$ & $\begin{array}{l}11 \\
17 \\
28 \\
44\end{array}$ \\
\hline Fox Chase & 14,051 & 829 & $\begin{array}{l}\text { Caucasian } \\
\text { Asian } \\
\text { African American } \\
\text { Hispanic }\end{array}$ & $\begin{array}{r}92 \\
3 \\
3 \\
2\end{array}$ & 4 & $\begin{array}{l}\text { Below } 12 \text { th grade } \\
\text { High school graduate } \\
\text { Some college } \\
\text { Graduate }\end{array}$ & $\begin{array}{l}10 \\
35 \\
34 \\
21\end{array}$ \\
\hline Roxborough & 36,052 & 6,770 & $\begin{array}{l}\text { Caucasian } \\
\text { African American }\end{array}$ & $\begin{array}{r}95 \\
5\end{array}$ & 0 & $\begin{array}{l}\text { Below } 12 \text { th grade } \\
\text { High school graduate } \\
\text { College }\end{array}$ & $\begin{array}{r}6 \\
73 \\
21\end{array}$ \\
\hline Chestnut Hill & 10,168 & 1,239 & $\begin{array}{l}\text { Caucasian } \\
\text { African American } \\
\text { Other }\end{array}$ & $\begin{array}{r}73 \\
25 \\
2\end{array}$ & 0 & $\begin{array}{l}\text { Below 12th grade } \\
\text { High school graduate } \\
\text { Some college } \\
\text { Graduate }\end{array}$ & $\begin{array}{l}11 \\
16 \\
47 \\
26\end{array}$ \\
\hline Nicetown & 43,211 & 11,692 & $\begin{array}{l}\text { African American } \\
\text { Caucasian } \\
\text { Hispanic }\end{array}$ & $\begin{array}{r}71 \\
9 \\
20\end{array}$ & 33 & $\begin{array}{l}\text { Below 12th grade } \\
\text { High school graduate } \\
\text { Some college } \\
\text { Graduate }\end{array}$ & $\begin{array}{r}44 \\
33 \\
17 \\
6\end{array}$ \\
\hline Lehigh & 33,106 & 10,422 & $\begin{array}{l}\text { African American } \\
\text { Hispanic/Latino } \\
\text { Caucasian }\end{array}$ & $\begin{array}{r}41 \\
57 \\
3\end{array}$ & 51 & $\begin{array}{l}\text { Below 12th grade } \\
\text { High school graduate } \\
\text { Some college }\end{array}$ & $\begin{array}{r}54 \\
40 \\
3\end{array}$ \\
\hline Kensington & 14,786 & 4,890 & $\begin{array}{l}\text { Caucasian } \\
\text { Hispanic } \\
\text { African American }\end{array}$ & $\begin{array}{r}65 \\
26 \\
6\end{array}$ & 46 & $\begin{array}{l}\text { Below } 12 \text { th grade } \\
\text { High school graduate } \\
\text { Some college }\end{array}$ & $\begin{array}{r}4 \\
85 \\
11\end{array}$ \\
\hline Kingsessing & 35,436 & 9,686 & $\begin{array}{l}\text { African American } \\
\text { Caucasian } \\
\text { Other }\end{array}$ & $\begin{array}{r}82 \\
10 \\
8\end{array}$ & 90 & $\begin{array}{l}\text { Below 9th grade } \\
\text { Below 12th grade } \\
\text { High school graduate }\end{array}$ & $\begin{array}{r}5 \\
30 \\
65\end{array}$ \\
\hline
\end{tabular}

ing, and momentary time sampling strategies used for analyzing applied problems and questions. Each week we reviewed our data, summarized our findings, and raised new issues. In this respect, questions arose from the data-gathering process itself, leading to a fluid, hypothesis-generating set of inquiries, four of which are presented here.

To examine how similar resources were used by different socioeconomic communities, we report on studies that highlight (a) reading in low- and middle-income neighborhoods (prior to technology and renovations); (b) activities in the prekindergarten areas right after renovations; (c) recreational reading for elementary-age children and teens before and right after renovations; and (d) computer use after the novelty period, approximately one year after renovations were completed. Throughout these inquiries, we must remind readers that the technological enhancements described here are, by now, dated and should not be interpreted as the latest technolo- gies in urban libraries. Rather, these studies provide information on the integration of technology in children's lives and its ramifications for low-income and middle-income children. Although each study provided a wealth of information on a particular targeted inquiry (Neuman, 2001a) our analysis here was to weave these studies together toward a theoretical understanding for how policies of equalizing resources might influence low-income and middle-income children.

\section{Method}

\section{Library use in low-and middle-income neighborhoods}

This first analysis was designed as a foundational study, providing an estimate of typical use patterns in low- and middle-income neighborhoods 
TABLE 2

TIMELINE OF TARGETED STUDIES

\begin{tabular}{|c|c|c|c|}
\hline Study & Data collected & Analysis & Key findings \\
\hline \multicolumn{4}{|c|}{ Study 1: Before technology and renovations } \\
\hline $\begin{array}{l}\text { Reading activity in low- and } \\
\text { middle-income neighborhood } \\
\text { libraries }\end{array}$ & $\begin{array}{c}\text { Duration coding of reading } \\
\text { materials in four libraries }\end{array}$ & $\begin{array}{l}\text { Tallies of the time spent on } \\
\text { reading in low- and middle- } \\
\text { income neighborhood libraries } \\
\text { Challenge level of materials }\end{array}$ & $\begin{array}{l}\text { Children in low- and middle- } \\
\text { income neighborhood libraries } \\
\text { spend approximately similar } \\
\text { amounts of time in library, } \\
\text { but challenge level is different }\end{array}$ \\
\hline \multicolumn{4}{|c|}{ Study 2: Before and after technology and renovations } \\
\hline Preschool activity setting & Observations in four libraries & $\begin{array}{l}\text { Constant comparative method } \\
\text { Single bounded episodes }\end{array}$ & $\begin{array}{l}\text { Children in middle-income } \\
\text { neighborhood libraries were } \\
\text { mentored in how to use library } \\
\text { resources; children in low- } \\
\text { income neighborhood libraries } \\
\text { were not }\end{array}$ \\
\hline \multicolumn{4}{|c|}{ Study 3: Before and immediately after technology and renovations } \\
\hline $\begin{array}{l}\text { Reading behaviors in print areas } \\
\text { of library and computer areas }\end{array}$ & $\begin{array}{l}\text { Typology of print and computer } \\
\text { behaviors developed } \\
\text { Momentary time samplings of } \\
\text { print and computer use in } \\
\text { four libraries }\end{array}$ & $\begin{array}{l}\text { Percentage of time and how it } \\
\text { was used in each setting }\end{array}$ & $\begin{array}{l}\text { Percentage of time for reading } \\
\text { went up after technology and } \\
\text { renovations but it went up more } \\
\text { for children in middle-income } \\
\text { neighborhood libraries }\end{array}$ \\
\hline \multicolumn{4}{|c|}{ Study 4: After technology and renovations had been in place for a year } \\
\hline Computer activity & $\begin{array}{l}\text { Duration codings of time and } \\
\text { activity in computer setting/ } \\
\text { number of lines of print read } \\
\text { Challenge level }\end{array}$ & $\begin{array}{l}\text { Tallies of time/number of lines } \\
\text { of print } \\
\text { Challenge level across } \\
\text { four libraries }\end{array}$ & $\begin{array}{l}\text { Children in middle-income } \\
\text { libraries read more and engaged } \\
\text { more in challenging materials } \\
\text { than those in low-income } \\
\text { neighborhood libraries }\end{array}$ \\
\hline
\end{tabular}

prior to innovations and additional resources in libraries. Conceivably, if large differences in patterns of library use were found across different socioeconomic groups, then the question of whether or not resource allocations might be equal could be moot. Monthly circulation figures (considered the "currency" of a library) indicated widely disparate patterns across these neighborhoods (Gaul, 1997). However, we knew that circulation figures could be notoriously inaccurate for libraries in poor areas because of their heavy dependence on library registration, cards, and fines (Van House, 1983). Rather, several scholars have recommended in-building use studies, focusing on different output measures as a method to examine how people actually use the library. Previous studies (Immroth \& Lance, 1996), for example, have involved hour-by-hour sweeps of the number of books, newspapers, and magazines left on tables as indicators of the type of reading activity engaged in by adult, teen, and child patrons.

We sought a more closely detailed analysis of time spent in libraries. Focusing our analysis on children's activity, we carefully identified an activity set- ting in the library, defined as "a context with specific purposes, occasions and participants" (Tharp \& Gallimore, 1988), devoted to children's reading. Research assistants drew visual maps to identify the area in each library (see Figure 1).

We then conducted duration recordings (Axelrod, 1983) of children's reading activity. Duration recordings provide a measure of how long a child engages in a certain behavior (see example in Table 3). We conducted this analysis in four of the neighborhood libraries (two middle-income and two lowincome identified as such from our previous analysis) over three summer months. We selected these months to focus on recreational reading rather than reading that might be dictated by school assignments.

During each visit, two research assistants observed and recorded the actual age of the child entering the library, race/ethnicity, gender, time the child started and stopped reading a resource (book, magazine, or newspaper), number of different resources used during the stay, and the average time spent with each reading item. A research assistant was assigned to observe each new patron as he or she entered the 
FIGURE 1

MAPPING THE ACTIVITY SETTINGS IN LIBRARY

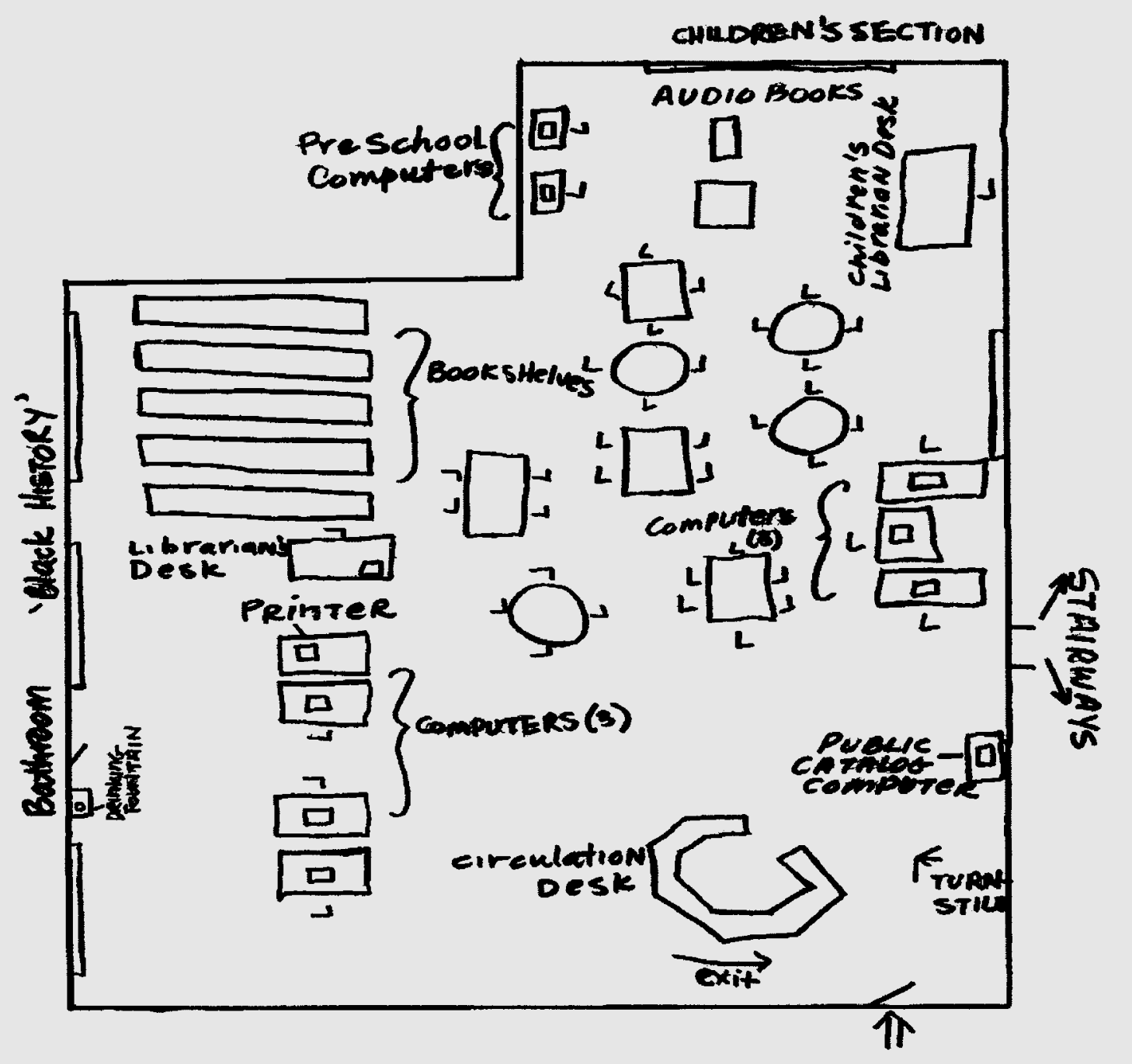

setting, established a start time as the other continued to observe other young patrons until they exited. During these observations, the research assistants worked as a team to identify ages of children, reading materials, and reading activity, resolving differences in observations through discussion. Therefore, we relied on peer examination to verify and check on the findings as they developed in real time to enhance internal validity (Merriam, 1998). Following observations, research assistants tabulated their time samplings. In total, observers visited libraries for 80 hours, 20 hours per library, conducting 2-hour ob- servations during the morning, early afternoon, and later afternoon hours.

In addition, observers would record the particular title of the book (or magazine or newspaper) in order to examine its potential difficulty level and estimate whether it reflected at, below, or above agelevel reading. Whenever possible, after the observations were conducted, we also examined an online catalogue detailing approximate age level of books. For example, a 13-year-old boy reading Arthur's Eyes (Brown, 1986) was regarded as a "belowage reading task" compared with an 11-year-old 
TABLE 3

AN EXAMPLE OF DURATION CODING: READING ACTIVITY IN THE LIBRARY

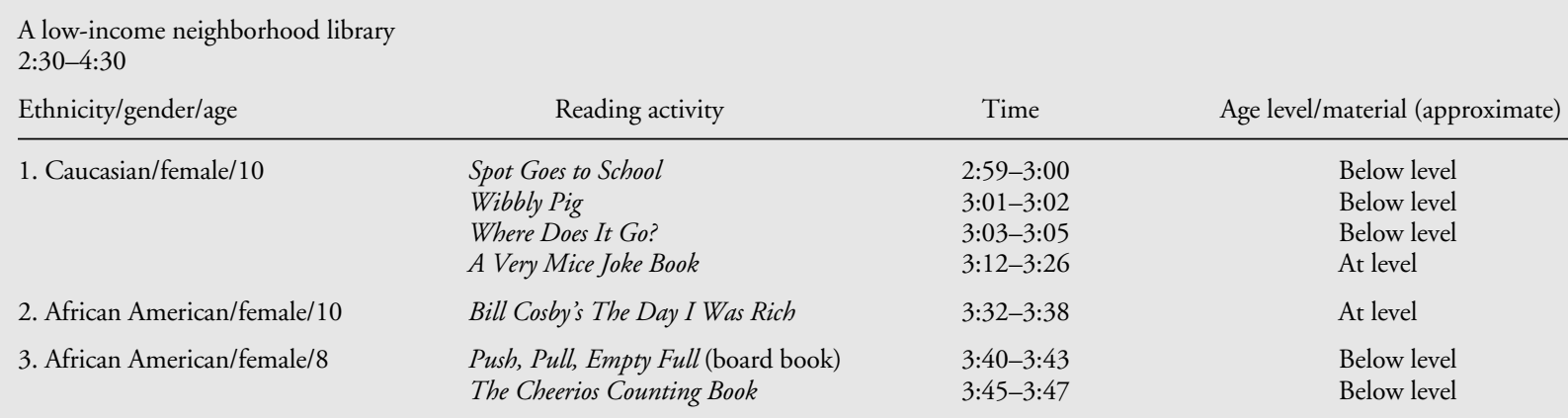

browsing juvenile nonfiction at age level. Though relatively crude, such coding of difficulty level provided us with some estimation of how time was spent in the library. Tallies were made across settings to examine differences in total numbers of children attending libraries, and average reading activities in middle- and low-income neighborhoods. Therefore, this in-building analysis represented the most detailed study of its kind to date (Immroth \& Lance, 1996), going beyond the examination of library activity merely on the basis of circulation figures, a metric that has typically privileged middle-income and upper-income communities.

\section{Preschool activity}

As a profoundly social process, early literacy development is embedded in social relations (McLane \& McNamee, 1990), and elaborated in settings like the neighborhood library. Given the influence of these early interactions with print, this study observed preschoolers after libraries had just been renovated to create a preschool activity setting and a computer with educational games. Rather than conduct timed analyses as for our other studies, here we conducted 20 hours of observations in four libraries (two low-income and two middle-income) for a total of 80 hours over late spring and summer months in order to understand how preschoolers were initially socialized in their uses of the library. Over a fourmonth period, research assistants visited the preschool area in two-hour visits in each library, writing observations, attempting to capture interactions with books, the approximate length of stay of the visit, and the family member generally accompanying the child. We viewed these early activities as potentially helpful in understanding how children in these different communities might relate to reading resources as they developed more formal reading skills.

Observations were conducted from an ecological perspective (Bronfenbrenner, 1979), as we tried to understand the relation between context, participants, and interactions that occurred within these distinctive new settings (Merriam, 1998). Each observation identified how the physical space was used, the participants in the setting, their roles, and the intended and unintended uses of space. Acting as unobtrusive as possible in such a setting, the observer tried to develop an understanding of the tacit rules of engagement and interactions among siblings, friends, and groups over time through conversations, nonverbal behavior, and silences. Each observation's field notes were then written in detail, with a summary and commentary that included the research assistant's interpretations and working hypotheses.

Using the constant comparison method, we discussed our weekly observations as a team, looking for commonalities and disjunctures across settings. Due to the often brief encounters in the setting (several seconds) and frequent entrances and exits, we attempted to describe and compare single bounded episodes holistically (Merriam, 1998).

(See sample of single bounded episodes in Table 4.) We began to construct categories and themes that appeared to cut across the data, comparing differences in who accompanied the young child, the activity in the setting, and the frequency of selecting books to read. Throughout these analyses certain patterns began to emerge in these settings, leading to more detailed questions addressed in our third study. 


\section{Timed recreational reading: Before and after technology}

This analysis examined reading for children in the elementary and teen activity settings or sections of the library, focusing on patterns of reading for low-income and middle-income neighborhood libraries both before and after technology integration. Unlike our previous studies, this analysis was designed to take a more microscopic look at reading, attempting to dig deeper into the types or purposes of reading activity than in our initial in-building use study.

We began this study by identifying different types of reading behaviors with print and computers. Recognizing that children often engaged in many different activities in relatively short periods of time (e.g., such as five minutes; see Table 3), we decided to take quick written "snapshots" of reading behavior in each activity setting (reading, computers), using a momentary time sampling strategy (Axelrod, 1983). Working together as a team, two research assistants would observe a child for 30 seconds, report a reading behavior, rest for 10 seconds, then observe the next child for 30 seconds. Following the observations, they would each make a list of behaviors that one could identify in an observation. Over the next two weeks, they refined the list, tried different activity settings, and experimented with different lengths of observation (15 seconds to 1 minute), finding that 30-second spans were most optimal. From this analysis, they developed a typology of reading behaviors for print and computers in these libraries. (See Table 5 for typologies.)

\section{TABLE 4 \\ EXAMPLE OF TWO SINGLE BOUNDED EPISODES IN PRESCHOOL ACTIVITY SETTING}

A low-income neighborhood library

- A 4-year-old girl is flipping through some board books in a bin. She picks up and peers at the cover. Do Not Open, it's called. She's mesmerized for a few seconds, looking at the cover-it's a forebodinglooking door. She looks like she's fascinated to find out what's behind the door. No one is around to read to her. Before long, she drops the book and scoots out of the area.

- A 10-year-old girl sits down with two 4-year-olds, a boy and a girl. They are flipping through books (looking at one, then another, then another). She takes Arthur's Reading Race and starts to read to them, one child at each side. She points to each word as she reads, wanting the children to learn each word. The little ones stay at her side for a while, but she reads haltingly and flatly. "Arthur....asked.. his...mother...." The little boy gets up after a minute and leaves. The little girl is trying to stay with the reading, but she too starts to fidget and look around. "Hey, look here when I'm reading!" the older girl scolds her. They finish the book, and the little girl runs away.

Research assistants attempted to independently code these behaviors over an observational period. Given the demands of the observation, they found it difficult to distinguish some behaviors from others (such as skimming, flipping, browsing). Therefore, we collapsed overlapping categories into three generic behaviors: reading (listening to text being read, including by the computer; reading by self; reading to another person); literacy-related activity (writing, typing, skimming over text, talking about text, browsing, looking at pictures in book); and other (wandering around, waiting, staring into space). Using these coding categories and protocol sheets, we selected three pilot sites (one high income and

\section{TABLE 5}

\section{A TYPOLOGY OF PRINT AND COMPUTER READING BEHAVIORS IN THE LIBRARY}

\begin{tabular}{ll} 
Print behaviors & Computer behaviors \\
\hline Reads to self & Reads to self \\
Writes & Types \\
Skims & Scrolls/skims \\
Handles print material/flips through text & Navigates around/within a program or page \\
Listens to text being read & Listens to text being read (by someone nearby) \\
Talks about text & Talks about text on screen/receives help \\
Reads to another person & Reads to another person \\
Browses (looking for reading materials) & Surfs/chooses new software or website \\
Looks at pictures only & Listens to/follows verbal directions on site or software \\
Other (e.g., draws, spaces out) & Other (e.g., waits, spaces out, talks to friends)
\end{tabular}


technologized; one low income and technologized; one low income and not yet technologized) to assess our methodology, and to determine the reliability and validity of our coding scheme. Two assistants independently coded children's behavior in these three categories, using 30-second momentary time samples, for two hours. Interrater reliability was .85.

Research assistants then used this observational approach to examine reading behaviors in four libraries (two low income; two middle income) for two sets of two hours each, before and after technology improvements. Some of the observations took place between 2:00 and 5:00 p.m.; other observations in early evenings when children were likely to be present. Within each two-hour set, assistants observed six 10-minute segments (with rest times following each segment), with each segment dedicated to a particular activity setting including the designated tables/stacks/and computer settings. For each segment, only (and all) children within that activity setting were observed (see Table 6 for example of momentary time samples).

To examine activity, the research assistant would observe one child at a time for 30 seconds, record the type of activity (reading, literacy related, or other), then move to the next child, cycling through as many times as possible in a 10-minute segment. Any and all activities were recorded. For example, within a 30 -second time period, a child might browse through books, then talk to a friend, then read again. For this observation, the research assistant would record three activities (read-talk-read), each of approximately 10 seconds duration. These data were translated into percentages of time spent on behaviors in each activity setting in each library. Six months following technology and renovations, we conducted the study again, using the same methodology, focusing not on the material itself but the type of reading behavior. After all data were gathered, we created a summary chart of reading activity from all four libraries to examine how technology integration and renovations might influence time devoted in libraries to reading.

\section{Computer-use study}

Our final analysis was conducted a year after technology renovations. Specifically, here we sought to examine children's use of computers once the novelty of the renovations had worn off. Our focus was to understand how children from different communities might use these computer resources and how they might help to level the playing field. We began with a pilot phase of data collection, first observing children's activities in the setting. Two research assistants were assigned to observe a child or teen as he or she entered the setting, record the material on screen, count the number of lines on screen, and record whether the material represented was challenging (above age level), at age level, or below age level. They also attempted to record the number of children milling around the children at the computer but found this too distracting. We found that research assistants could observe these activities within

\section{TABLE 6}

\section{EXAMPLES OF MOMENTARY TIME SAMPLING IN THE LIBRARY}

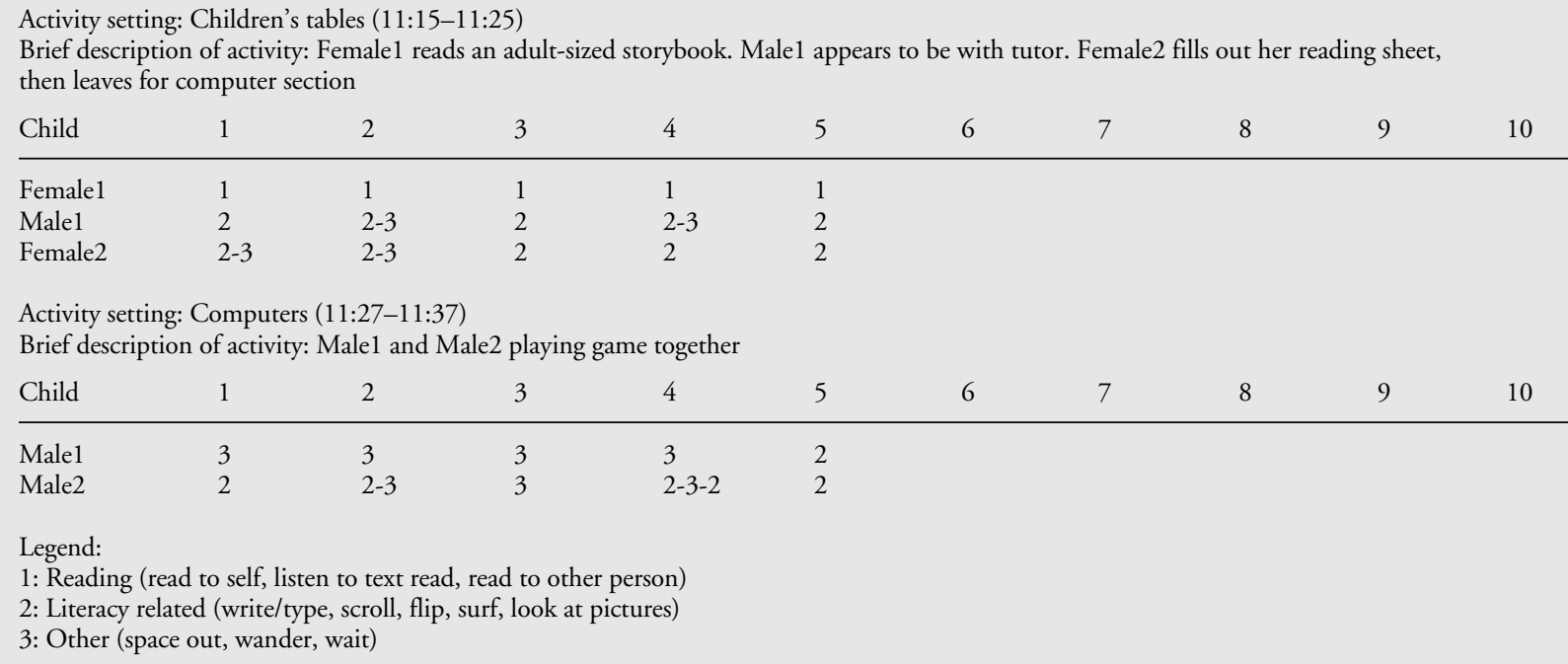


.75 to 1.00 agreement. At the same time, we decided to continue to use two assistants per visit to observe children's ease with computers, their interactions with people around them, and general library policies that might enhance or prevent children from making good uses of the technology.

As in our first in-building use study, two research assistants visited four libraries (low and middle income) for 40 hours (10 hours per library) over a six-week time span. Entering the computer-activity setting (computers were grouped together), the assistants would count the number of children using the computers, the type of application or site (e.g., Ultimategames.com-Bomber man), and the length of computer use per sitting. In addition, research assistants counted the number of print lines on the screen and the approximate age appropriateness of the materials. For example, a 12-year-old playing a child's math application program would be coded as below age level; a 10-year-old using children's typing program as approximately at age level (see example of data collection, Table 7).

They also observed overall behavior around the computer, including children's ease with computers, and their interactions with people around them. At the same time, they collected demographic characteristics such as age, gender, and ethnic background. All observations were conducted from 3:00-5:00 p.m., during the heaviest use periods for children's computer activity. Tallies of behaviors and activities were computed, and summaries of behaviors were recorded.

Therefore, these studies nested within our larger investigation of the community initiative, allowed us to test a range of important hypotheses about the influence of material resources for children from differ- ent socioeconomic communities. Methods devised, although imperfect, enabled us to track the unfolding of the assumptions underlying this broad-based initiative (Hollister \& Hill, 1995), creating interim markers that provided useful feedback and information on whether the initiative was accomplishing the objective for which it was funded. Together, with use of a mosaic of methodologies, these methods captured the rich and varied recreational reading activities in neighborhood libraries as they transformed from book-only to technologized environments. And they also provided a telling portrait of the influence of technological changes and socioeconomic inequality on reading development.

\section{Results}

Analyses revealed contradictions to conventional wisdom as well as troubling convergences across studies. Contrary to expectations (e.g., circulation figures, annual reports), studies indicated heavy library use across neighborhoods. Children of all ages - preschoolers, primary school children, and teenagers-whether they came from low-income or middle-income neighborhoods, filled library buildings consistently, using all forms of library resources, books, magazines, videos, and, when available, computers. Such patterns of use strongly contradicted the view that libraries were underutilized in poor communities (Gaul, 1997).

But the quality of time spent in the libraries varied substantially by socioeconomic status. These quality differentials appeared at all age levels prior to, immediately after, and stronger still following technology renovations. Together, these studies suggest

\section{TABLE 7}

\section{AN EXAMPLE OF DURATION CODING: COMPUTER ACTIVITY IN THE LIBRARY}

\begin{tabular}{|c|c|c|c|c|c|}
\hline \multicolumn{6}{|c|}{ Middle-income neighborhood library } \\
\hline Gender/age & Ethnicity & Activity & Time spent/minutes & Number of lines of print & Age/level \\
\hline Male/10 & Caucasian & Encarta Virtual Globe & 30 & 2 & At level \\
\hline Male/10 & African American & Netscape Cartoon Network & 20 & 0 & Below \\
\hline Female/6 & Caucasian & $\begin{array}{l}\text { Green Eggs and Ham } \\
\text { Netscape Cartoon Network }\end{array}$ & $\begin{array}{l}20 \\
10\end{array}$ & $\begin{array}{l}4 \\
0\end{array}$ & $\begin{array}{l}\text { At level } \\
\text { At level }\end{array}$ \\
\hline Male/12 & Caucasian & $\begin{array}{l}\text { Netscape FBI website } \\
\text { Yahoo Snakes } \\
\text { Yahoo Gorillas }\end{array}$ & $\begin{array}{r}15 \\
10 \\
5\end{array}$ & $\begin{array}{l}20 \\
20 \\
20\end{array}$ & $\begin{array}{l}\text { Above } \\
\text { At level } \\
\text { At level }\end{array}$ \\
\hline Male/8 & Caucasian & Netscape Famous Generals & 10 & 10 & Above \\
\hline
\end{tabular}


that technology and greater resources did not close the gap. Instead, they seemed to exacerbate it.

\section{Prior to technology and renovations}

Prior to technology and renovations, observations indicated that libraries were well used by children from advantaged and disadvantaged neighborhoods. Although there were differences in library attendance, observations indicated striking similarities in overall patterns of time use in libraries across socioeconomic levels. Tallies showed 157 children took advantage of the libraries from lowincome neighborhoods as compared with 115 for middle-income neighborhoods. Accumulated total reading time for children in libraries in low-income neighborhoods was 1,523 minutes, with an average reading time of 9.7 minutes per observation; accumulated time for children in middle-income neighborhoods was 1,153 minutes, with 10 minutes per observation (see Table 8).

Children from low-income neighborhood libraries also compared similarly in the number of materials they read during their average library visit. On average they read 2.6 different materials (e.g., books, magazines, encyclopedias), compared with those from middle-income neighborhoods who read 2.2 materials per library visit. Children in middleincome neighborhood libraries spent on average 4.5 minutes reading a book or resource before switching to another reading choice; low-income children averaged slightly less at 3.6 minutes.

But here the similarities ended. Observations indicated striking differences in the perceived challenge of materials used (see Figure 2). Children in low-income neighborhood libraries selected books and resources at their age level $58 \%$ of the time. However, $42 \%$ of the time they read below-age-level materials. It was relatively common, for example, to see early teens reading rap lyrics off the Web or playing online adventure games (identified as at-age-level materials). Nevertheless, it was also quite common to see early teens reading Highlights magazine, books from the Arthur series, even board books - materials far below their age level. These figures contrasted sharply with materials selected by children in middleincome neighborhoods. No below-age-level reading was recorded; rather, children largely read at age level $(93 \%)$, with a small percentage of reading more challenging above-level materials (7\%).

Of course, it could be possible that selections were a conscious choice, based on students' perceived (or real) reading ability. Because our observations were designed to be nonintrusive, we could not determine the reasons for such choices. However, given these wide disparities in choices, we hypothesized that they might be rooted in how children used the libraries, beginning in the earliest years. Consequently, we turned to an analysis of the preschool section, attempting to understand how children might be socialized to use libraries and to engage in their resources early on.

\section{Preschool section}

Table 9 summarizes our observations in lowand middle-income neighborhood libraries, before and right after technology was introduced in the preschool section. Observations indicated stark differences in attendance, activity, length of stay, checkouts, and, following renovation, computer use.

TABLE 8

ACTIVITY IN PUBLIC LIBRARIES PRIOR TO RENOVATIONS

\begin{tabular}{lll} 
& Middle-income neighborhood & Low-income neighborhood \\
\hline Number of children visiting library & 115 & 157 \\
Gender & $70 \%$ female & $50 \%$ female \\
& $30 \%$ male & $50 \%$ male \\
Average age of child & 7 years old & 8 years old \\
Accumulated minutes of reading time & 1,153 minutes & 1,523 minutes \\
Average reading time per child & 10 minutes & 9.7 minutes \\
Number of minutes per reading activity & 4.5 minutes & 3.6 minutes \\
Number of various reading materials per child & 2.2 materials & 2.6 materials
\end{tabular}


FIGURE 2A AND 2B PRIOR TO TECHNOLOGY

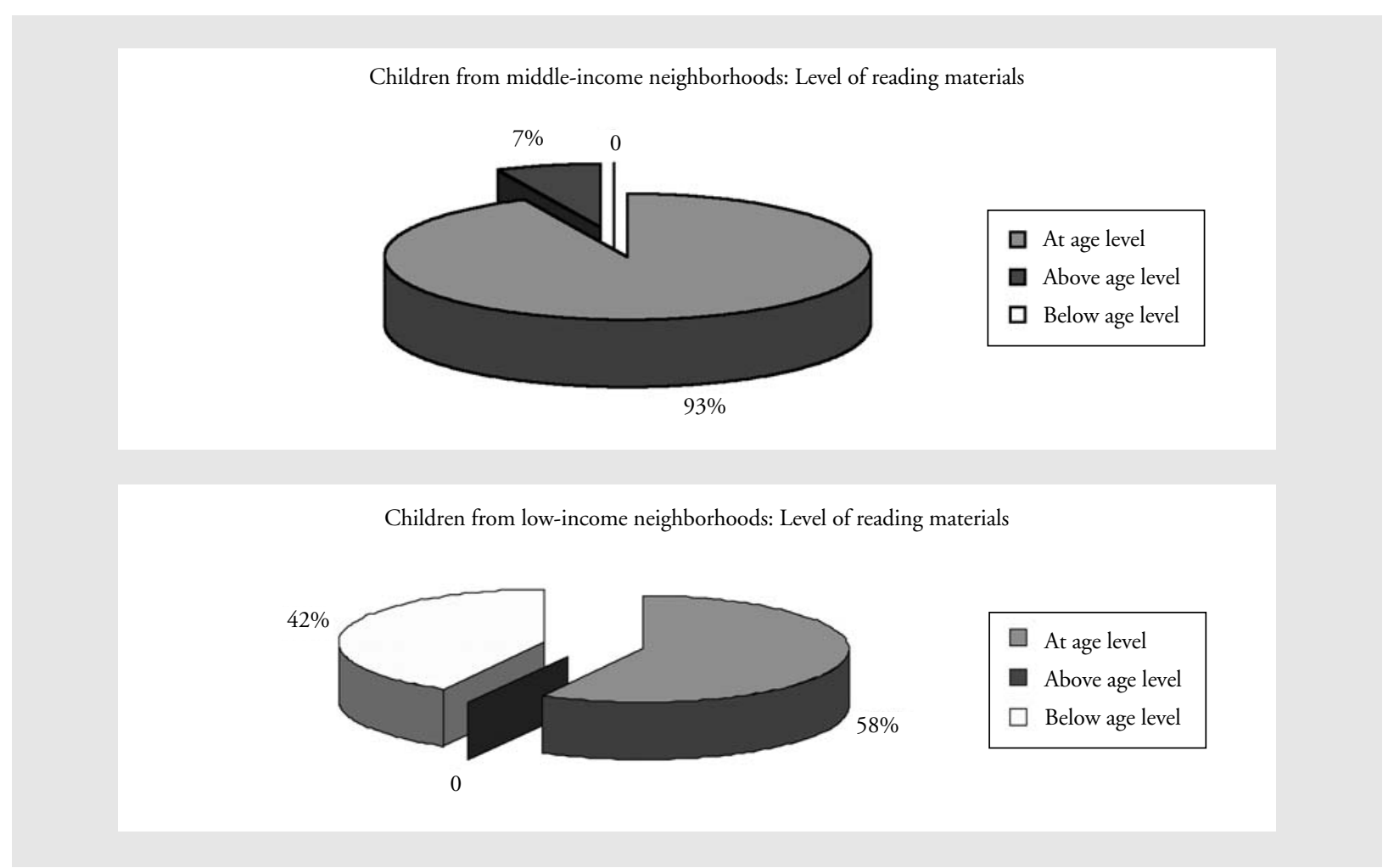

Children from middle-income neighborhoods always entered the preschool section accompanied by an adult, most often their mother, but occasionally a father, grandmother, or babysitter. In contrast, children in low-income areas entered alone or with a peer, sometimes with a sibling, but rarely with an adult. With little to do, they would wander in and wander out. Many hours were observed with no activity in the area at all.

Accordingly, activities in the preschool section varied dramatically for children. For children from middle-income neighborhoods, activities were highly focused. Invariably, the accompanying adult took charge, suggesting books, videos, or audiobooks to check out. Sometimes the parent might pull a book down and let the child examine it, or ask a child what types of books to look for. But the parent clearly appeared to be the arbiter for book selection, noting "That book is too hard for you," or "That is too easy," or "This one might be better." Parents steered children to challenging selections, sometimes appeasing them with a video selection as well. Visits tended to be brief, highly focused, highly routinized, and, without exception, ended with checkouts of books and, often, videos.

For example, a boy, age 5, and his mother in the preschool area from a middle-income neighborhood came into the preschool section:

The boy looks at the computer. "You have to sign up for them," his mother tells him, "so we can't do it right now." She finds a librarian. "Can you show us some scary books for him?" "Does he scare easily?" the librarian asks her. "No, are you kidding?" the mom laughs. The mom and son then select a few books. "These are scary books that I can read to you," the mom tells him. "We can get two if you want."

Here is another example:

A mom with a little girl, age 4, are picking out some books in the preschool area. They do not stay long. "Oh, look, they have Brown Bear!" the mom tells the little girl, trying to steer her toward books in a basket on the floor. The girl, however, is more interested in the nearby rack of videos. "No tapes," the mom says. "You have so many tapes at home. Let's get some books." She picks up about 10 books, and they go to the checkout desk. 
TABLE 9

\section{ACTIVITY IN THE PRESCHOOL SETTING: BEFORE AND RIGHT AFTER RENOVATIONS}

\begin{tabular}{lll} 
& Middle-income neighborhood libraries & Low-income neighborhood libraries \\
\hline Attendance in library & $\begin{array}{l}\text { Always accompanied by an adult/parent/caregiver } \\
\text { Child given great deal of direction/scaffolding highly } \\
\text { interactive }\end{array}$ & Rarely with adult; more likely alone, or with peer/sibling \\
Adult analyzes appropriateness of selections for children,, & No guidance \\
gook selection & Books always checked out & No checkouts \\
Checkouts & Relatively short but purposeful visits (about 20 minutes) & $\begin{array}{l}\text { Long visits (sitting with others in other areas of library) } \\
\text { Often frenetic, short bursts in preschool area }\end{array}$ \\
Length of stay & Child and parent engaged in activity & $\begin{array}{l}\text { Child alone or with older children } \\
\text { If around, adult inactive }\end{array}$ \\
Librarian assistance & Not available & Not available
\end{tabular}

Here is another example from the same library:

A mom heads over to the preschool area with two children. "These are books on kittens and cats," she says to the girls. They sit down on a bench, and the mom starts reading but then realizes the text is really too difficult and boring for the girls. "Oh, look," the mom says, "this cat is having kittens." The girls respond to the mom's questions. They close the book. Then one girl picks up another cat book (it looks very old). Mom says gently, "No, I think this one is better" (picking up a more recently published book). They grab the book and go to the checkout.

In contrast, children from low-income neighborhoods received little direction. Occasionally an older child might help locate a book or read to them. But more often than not, preschooler activity would appear as short bursts, almost frenetic in nature. A child would enter the section, run around, find a book, quickly flip through some pages, and then leave. With little direction, children would pick up books far too difficult for them or much too easy. Although average visits to the library tended to be longer than those of their middle-income counterparts, often the children's time would be spent sitting with their siblings in other sections of the library. Rarely did we see a book checked out. Here are some examples:

A boy, age 5, comes in to the section, takes a Richard Scarry board book from a basket, sits at a low table, and flips through the pages. This is a book with single words next to the pictures, and it seems to hold his interest for only a minute or two. He puts it down, and picks up a Magic School Bus book. He flips through this, but it holds his interest for even less time. The books are complicated, with complex ideas and hard words and are dense with print. He puts the book down and walks out.
Four boys, around 5 years old, wander in. They pick up some picture books from various bins in the area. They each spend about three minutes leafing through the pictures, put the books down, and leave.

Technology enhancements (one computer in the preschool section) did not appear to substantially influence these patterns. Visits for children in both neighborhoods might last longer (for example, the average 20-minute visit for a children from a middleincome community could last as long as an hour, and for children from low-income neighborhoods 2 hours, or the bulk of the day), but the level of involvement or noninvolvement remained the same. Parents from middle-income neighborhoods, however, did not universally approve of computers in the library. Frequently, parents would point out, "We're not here for the computers. We're here for the books." But especially in the beginning when children would gravitate to the computer anyway, mothers would remain highly involved in the process. They would sit close to the child, answer questions, and give suggestions.

Scott, 4 years old, and his mom are having a great time playing a math game. Scott is using the mouse and generally doing OK. His mom gives directions, encouragement, and suggestions on how to play. She's very involved, laughing when something amusing happens on the screen and rubbing Scott's back when he does something right. She is seated very close to the screen, leaning forward and looking very interested. Mom says, "See, that one has seven jellybeans, but you need five jellybeans for it to go into the five slot." Scott asks, "What about the zero?" Mom replies, "Well, then you have to take them all out." They continue to play for a few minutes and then leave with books. 
Children from low-income neighborhoods, without adult supervision, often used the keys of the computer, like play. Some times the technology aide would help get the child started on a particular game. But then frustration would set in, and the child would frenetically start pounding on the keys, then run in another direction. Sometimes, gangs of older children would come to the child's assistance, yelling instructions. Other times, they would take over, and turn to websites that had no educational value or, worse, graphic displays of violence.

On the rare occasion when an adult was present, there was little supervision or interaction, almost as if the adult was intimidated by the technology. Here is an example:

\begin{abstract}
A mom and her four tots, about 3 and 4 years old, are watching the Green Eggs and Ham CD story play. It is very much like TV - the words come up and a narrative tells the story, accompanied by sounds and music. The group watches it for about 10 minutes. Mom sits toward the back of the group. She says nothing, and there is no interaction or discussion about the computer activity at all. The children are glued to the screen. After Green Eggs and Ham is finished, one of the children pulls up a math game. This program requires more involvement on behalf of the group. One child controls the mouseball; the others are really lost about what to do. "How do you do this?" one boy asks the mom. She shakes her head; she does not offer help. The boy clicks away; he is really lost. Soon an older girl, around 12 years old, comes over and takes control. She doesn't say much but actually does the activity as the other children watch. After a few minutes, the mom gets up. "Come on, it's time to go." They leave but do not check out any materials.
\end{abstract}

These observations provided insight on the differences found in book selection in the previous study. Preschoolers in middle-income neighborhoods appeared to be carefully mentored in selecting challenging materials; those in low-income neighborhoods received little, if any, coaching. Left on their own, these children resorted to playful activity of short bursts, picking books up and putting them down with little discrimination and involvement. Because children lacked familiarity with the computer and computer games, keyboards became play objects of interest more for their color displays than their content.

Additional titles and technology enhancements, then, hardly leveled the playing field, in fact, quite the contrary. Despite their misgivings, parents in middle-income neighborhoods carefully orchestrated children's activities on the computer, much as they did with books. For low-income children, no such mentoring was available-they were on their own. Such differences appeared to profoundly influ- ence the ways in which the technology was used and the quality of that use.

Caught in the initial stages of technology integration, busy librarians offered little supervision and assistance. We found them equally absent in nearly all observations of the preschool areas.

\section{Recreational reading: Before and after renovations}

Finding that patterns of use with technology in the preschool area tended to mirror engagement with books, we turned next to the children's section, most frequented by elementary-age children and those in their early teens. Here, we sought to examine children's activities, largely independent of any adult intervention, in greater detail, before technology and renovations and after they had been in place for at least six months. With multiple information sources and ability to engage children's interest and motivation (de Jong \& Bus, 2004), might equal access to computer resources in addition to books place children of different income status on equal footing? Once again, the focus of our observations was on the activity setting and the types of engagements in these sections across different neighborhood libraries.

Figure 3 shows that, prior to technology enhancements, reading activity appeared relatively similar across different socioeconomic levels in libraries. Children spent about $15 \%$ of their time reading in middle-income neighborhood libraries; a little over $14 \%$ of the time for children from low-income neighborhoods. Middle-income children, however, spent more time talking about reading than lowincome children, roughly $10 \%$ more time than the others. But the figures also showed that all children, regardless of income level, spent much of their time not doing much at all. About $40 \%$ of the time middle-income children just hung around, wandered, and stared into space; the figure was $50 \%$ for low-income children.

The gap between the two groups on time spent reading did not close six months later after technology enhancements. Instead, it grew larger (see Figure 4). Children in middle-income neighborhoods almost doubled the amount of time spent reading following the introduction of technology. Time increased only marginally for low-income neighborhood children. In all libraries, literacy-related talk decreased substantially, indicating an overall loss of reading and reading-related activity for low-income children. Children now spent even more time 


\section{FIGURE 3}

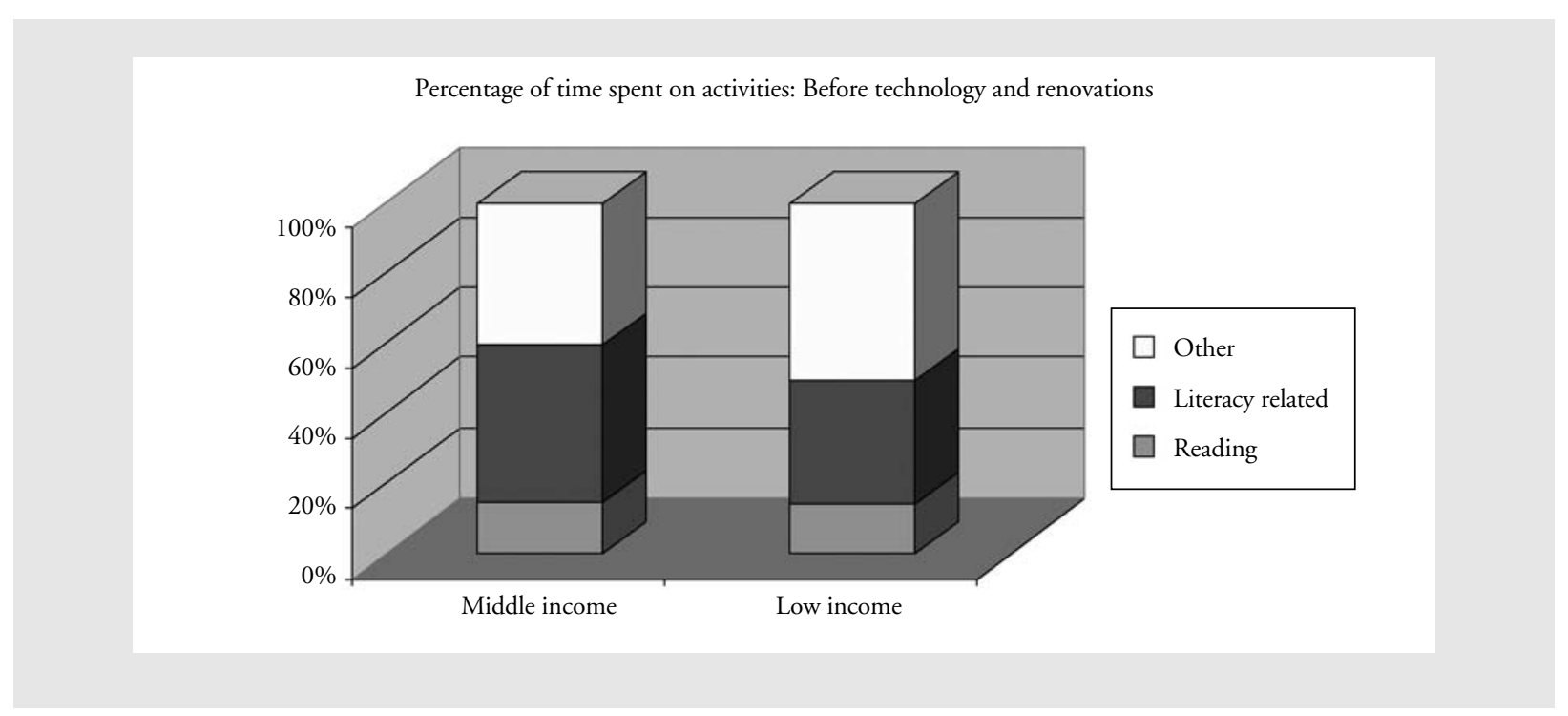

FIGURE 4

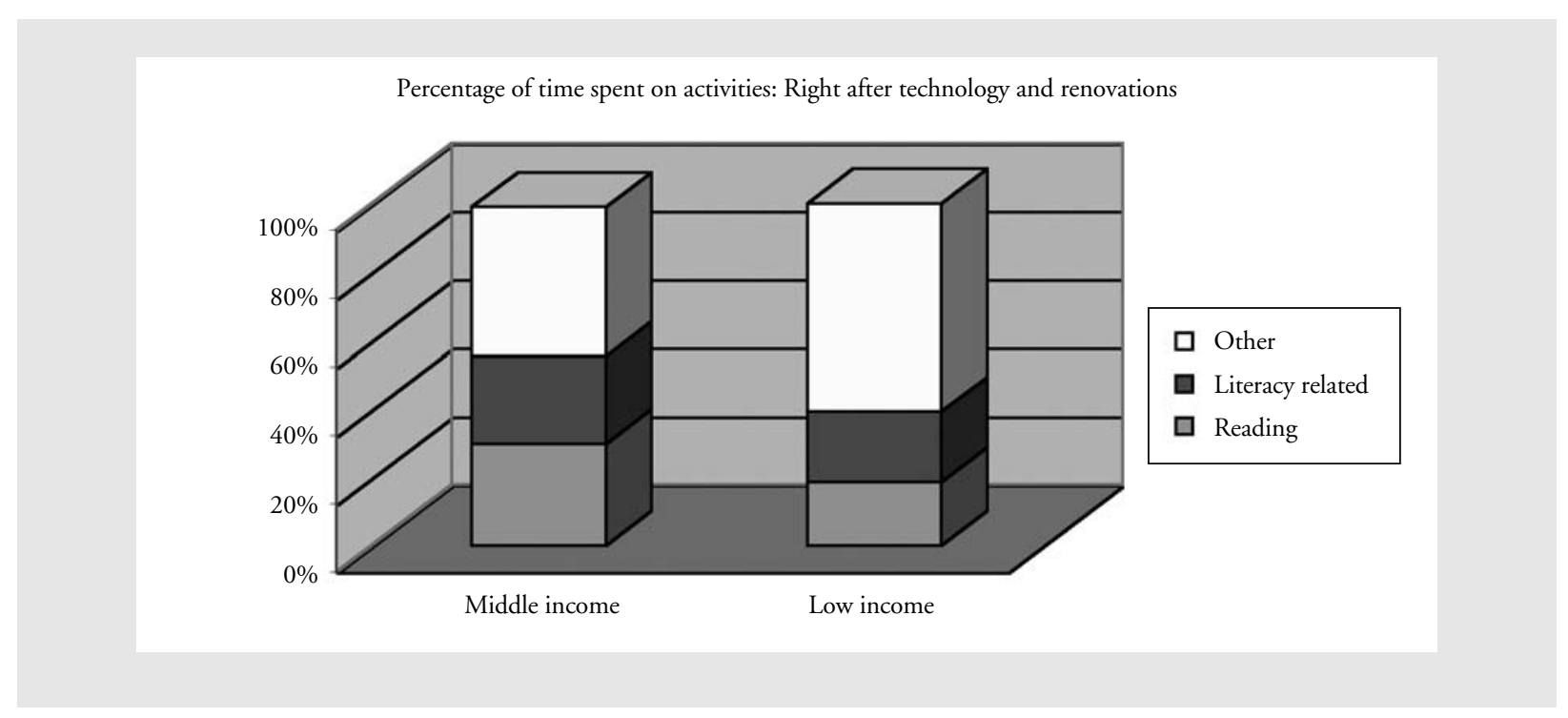

hanging out or wandering around (e.g., probably "waiting" to get on the computer).

Rather than promoting reading, technology (as it was used here) appeared to displace reading for low-income neighborhood children. From Internet golf games to time spent waiting for a program to load, the novelty of the computers appeared to take time away from reading-related activities.

Computers appeared far more tantalizing than books. As one librarian found, "Books are something you look at while you wait for a computer."
But these patterns are certainly not unprecedented. New technologies can initially displace other media, like reading books and newspapers. Research suggests (Himmelweit, Oppenheim, \& Vince, 1958; Schramm, Lyle, \& Parker, 1961), however, that once the novelty has worn off, activities usually return to previous levels, although their functions might change in the process. For our analysis, we sought to understand whether computers with their motivational capabilities and flexibility of use might bootstrap children's learning by providing equal access to 
information. Especially once they had become ubiquitous, might computers close the gap?

\section{Children's computer use}

We examined computer activity one year later. The gap had not closed; in fact, there was evidence of a growing gap. Even though low-income neighborhood children spent slightly more minutes on computer activities, results indicated quality differentials in the time per application, purpose, amount of reading, and the degree of challenge in reading. Once again, it was clear that equal resources did not translate to equal educational experiences.

As shown in Table 10, low-income neighborhood children visited the computer section more frequently than middle-income children. Nevertheless, the ways in which they used their time differed dramatically. Children from low-income neighborhoods spent a good deal of computer time on gaming activities that contained little print; children from middleincome neighborhoods spent more time on content applications with more print. Consequently, lowincome children averaged 3.9 lines of print during computer use, in contrast to 11 lines of print per computer application for middle-income neighborhood children.

The following observations highlight these differences. The first involves an African American girl, age 11 , from a low-income neighborhood:
3:30-4:00

3:30 Magic School Bus (1 line of print per slide)

3:31: Netscape, types cluelesstv.com. Does not get desired results. Types in other websites: bonustv.com

3:35: She does not seem to get the website she wants. Does not ask for help.

3:40: Not happy with web searches, goes to Math Blaster: total 10 lines of print

3:42: Back to Netscape. Types in www.brideofchucky.com (horror movie).

3:45: Watches many pictures from movie.

4:00: Finished.

In contrast, the next observation of an African American boy, age 10, is from a middle-income neighborhood:

3:40 Sits down at the preschool area (only computer available) and clicks immediately on Encarta Encyclopedia. Types in "Christopher Columbus." Gets article with pictures, maps, and information on Columbus's life and travels. Reads through it, looking for certain things that he checks against a list from school. When he finds the items in the article, he says, "There it is." He then starts a new search on Henry Hudson. He shows the observer his assignment-a list of aspects of Hudson's life that need research. He reads through the article, looking for the specific things requested on the list-Hudson's life, where he went, maps, and a picture. He highlights certain things to be printed and tries printing them out.

4:05: He leaves.

\section{TABLE 10}

CHILDREN'S COMPUTER USE IN LIBRARIES

\begin{tabular}{lll} 
& Middle-income neighborhood libraries & Low-income neighborhood libraries \\
\hline Total hours of computer use observed & 20 hours & 20 hours \\
Total minutes of computer use observed & 1,210 minutes & 1,241 minutes \\
Gender & 21 males & 39 males \\
& 21 females & 27 females \\
Ethnic background & $12 \%$ & $92 \%$ \\
African American & $78 \%$ & $3 \%$ \\
Caucasian & 0 & $5 \%$ \\
Hispanic & $10 \%$ & $0 \%$ \\
Indian & 28 minutes & 18 minutes \\
Average time child spent on computer & 23.7 minutes & 4.6 minutes \\
Average number per application & 11 lines & 3.9 lines \\
Number of lines of print per child & $35 \%$ & $6 \%$ \\
Percentage of children doing homework & &
\end{tabular}


These observations drew attention to the purposes for using the computer. Children from middleincome neighborhoods were more likely to use computers for school assignments - applications at a higher level than games and containing more print. Some 35\% of these children's time was spent working on school projects, including searching through encyclopedias, doing online research, or typing reports. Only $4 \%$ of the children's time in low-income neighborhood libraries was spent using the computer for these purposes. For example, observing on one December afternoon at a low-income neighborhood branch, we found 1 out of 10 children engaged in a school assignment, compared with 5 out of 6 children at a middle-income branch. These differences, of course, could reflect differences in the amount and type of homework assigned in low- and middleincome neighborhood schools (e.g., Wang, Haertel, \& Walberg, 1993, have documented limited homework assignments for low-income children, even though the School District of Philadelphia had a policy of one to two hours of homework per night). Still, without inferring causal attribution, there were striking differences between groups.

The activity, therefore, influenced task persistence. Gaming tended to be frenetic; school assign- ments were more goal oriented. Children in middleincome neighborhood libraries spent longer periods on the computer and longer times on one application. Average time for low-income neighborhood children was 18 minutes, with 4.6 minutes per application. Average time for middle-income neighborhood children was 28 minutes, with 23.7 minutes per application.

When we look specifically at the age appropriateness of the materials, we see that results were strikingly similar to our first analysis. Children in low-income areas spent more time involved in tasks that were either at or below their age level. Children spent $51 \%$ of their time on age-level activities and $49 \%$ of their time-nearly half-on below-age-level activity. For example, it was not uncommon to see 12- and 13-year-old boys playing Magic School Bus, even though the software was designed for 6 through 9-year-olds; 6- and 8-year-olds were often seen playing Green Eggs and Ham, a game designed for preschoolers. Such below-age-level activity was infrequent in middle-income neighborhood libraries, where $7 \%$ of the time was spent on below-age-level reading, but $91 \%$ on age-level activities.

In summary, results showed consistent patterns across studies before and after technology and for

\section{FIGURE 5A AND 5B}

Computer use for children from middle-income neighborhoods: Level of reading ability

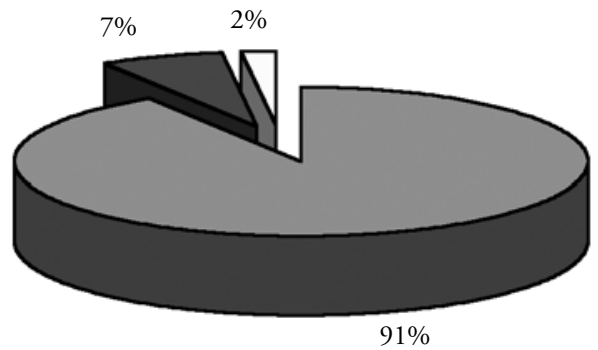

At age level

Below age level

Above age level

$91 \%$

Computer use for children from low-income neighborhoods: Level of reading ability

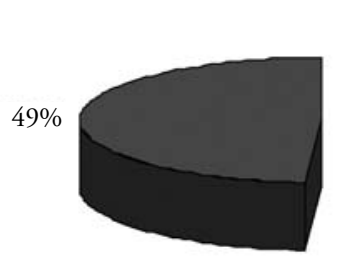

$0 \%$

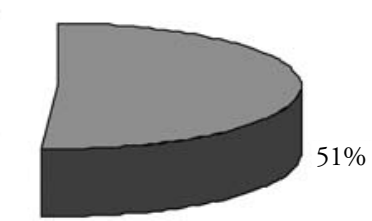

At age level

Below age level

Above age level 
younger and older children. Mentored to use its resources strategically from an early age, children from middle-income neighborhoods engaged in more purposeful learning at the library. In contrast, children from low-income neighborhoods, receiving little to no mentoring (from peers or siblings), had difficulty mastering the media and engaged in short bursts of lowlevel activity. Such routinized behavior in one medium, books, seemed to translate to a new medium, computer technology. These qualitative differences in use patterns, contrary to expectations, appeared even more transparent after a year had transpired. Therefore, far from leveling the playing field, technology and the renovations that supported it seemed to further substantiate the differences between groups. Closing the "digital divide" (Negroponte, 1996) appeared to widen the "learning divide." And, given the potential of this digital medium-its ready access to information, its speed of information flowthis divide may be very difficult to close.

\section{Conclusions}

Transforming libraries into a model urban library system with access to technology and renovations designed to attract neighborhood children and families to use their resources represented one of the most ambitious comprehensive community-based initiatives to provide equal access and opportunity for children of disadvantaged economic circumstances in this city's history. Given the substantial differences in socioeconomic levels in the city, library designers proposed to ensure that every child, regardless of whether or not they came from poor neighborhoods, would have equal access to highquality books (many related to their particular cultural tradition) and to computer technology to close the sizable gap in achievement.

To its credit, the project succeeded masterfully in providing equal access to resources, with 32 neighborhood libraries transformed over 5 years. But it did not succeed in providing equal outcomes. Technology and renovations inadvertently reinforced the gap that existed between children from different status backgrounds. Differences in the quantity of use more often favored low-income neighborhood children, while differences in the quality of use favored middle-income neighborhood children. Taken together, these studies confirm that equal resources to economically unequal groups do not level the playing field (Cook et al., 1975; McGill-Franzen, Allington, Yokoi, \& Brooks, 1999). In fact, as some studies have shown (Cook et al.; Mosteller $\&$
Moynihan, 1972), equal resources to unequal groups may actually exacerbate differences.

The 1969 debut of Sesame Street, designed specifically to narrow readiness disparities as part of U.S. President Johnson's War on Poverty, provides an illustrative example of the difficulties of closing the gap. The first- and second-year evaluations (Ball \& Bogatz, 1970; Bogatz \& Ball, 1971) of the program showed evidence of actually increasing differences, helping those children who were already somewhat prepared for formal reading instruction far more than the less ready children, who benefited little. As a result of the program, studies (e.g., Cook et al.) found, somewhat counterintuitively, larger gaps in skills by kindergarten for middle- and low-income neighborhood children than ever before.

In our studies, after technology and renovations we saw evidence of a gap in the amount of reading, in the purposes for reading, and in the difficulty levels of reading materials used among low- and middleincome neighborhood children. We define it as a knowledge gap, because reading is a major source of acquiring information, vocabulary, and abstract reasoning (Cunningham \& Stanovich, 1998; Stanovich \& Cunningham, 1993; Stanovich, West, \& Harrison, 1995). Our studies indicated that after the novelty of the new medium wore off, middle-income neighborhood children, in general, were reading approximately three times as much as low-income neighborhood children and using materials of far greater challenge. If these findings hold true to the knowledge gap hypothesis substantiated in the literature across other topic areas (Gaziano, 1997), these not-so-small differences may become insurmountable after only a few years. Further, given the new, more powerful, and more immediate technologies that now exist at reasonable costs, some might speculate that this gap could rise exponentially.

Communication theorists have consistently reported these findings (Viswanath \& Finnegan, 1996); however, there has been less agreement on the causal factors for why they occur. Hernstein and Murray (1994), for example, contended that higher socioeconomic status and higher intelligence (largely inherited) tend to coincide, creating a cognitive elite, which to all intents and purposes is permanent and therefore immutable to policies and programs. Challenging this argument, Fischer and his colleagues (Fischer et al., 1996) argued that the social environment explains people's cognitive abilities better than intelligence tests. Struggling with poverty, economically disadvantaged individuals tend to be information-poor. Deficiencies in knowledge not only lead to difficulties in learning to read, but also 
difficulties in acquiring new knowledge. Consequently, a child with well-developed, highly elaborated semantic networks consisting of a sizable number of schematic categories (Rumelhart, 1980) will have more ready and more fluent access to those categories and the information they subsume than would the child with less well-developed and less elaborated knowledge (Anderson \& Pearson, 1984; Bransford et al., 2000). As the infusion of knowledge increases, those segments in the population will likely acquire information at faster rates than lower status populations. It is the differential rate of information acquisition (Tichenor et al., 1970) that contributes to the growing knowledge gap.

So television, often hypothesized as a knowledge leveler, instead actually contributed to knowledge differentials (Cook et al., 1975). Communications scholars (Comstock, 1980; Salomon, 1984), however, have argued that television content is on average at the fourth-grade level; studies (Neuman, 1995; Salomon) show that learning definitely peaks over the elementary years due largely to the limitations of the medium. But computer technology, especially in its more recent applications, knows no bounds. Therefore, whether or not, or to what extent, newer technologies may further widen knowledge differentials is clearly a topic to be explored further (Bruce \& Hogan, 1998). However, we need to recognize, as Cuban (1986) attested in his historical analysis of media, that technologies have rarely contributed to learning to the extent originally theorized.

Therefore, short of denying equal resources, or redistributing information to equalize groups, how might we contain or reduce the knowledge gap? Continuing to level the playing field by providing the same level of resources to low-income neighborhood children and their middle-income peers, as shown in this study and other research (Coleman et al., 1966; McGill-Franzen et al., 1999), will not narrow the knowledge gap. Rather, we need to keep on going and consider first leveling (equalizing resources) and then tipping the balance in the other direction by providing more resources and additional supports to low-income neighborhood children (Carey, 2003). Theorists have proposed specialized interventions that involve a massive build-up of content knowledge (Bereiter \& Engelmann, 1966; Bransford et al., 2000; Hirsch, 1987, 2003; Neuman, 2001b) and more intensive early education with the understanding that small early deficits in intellectual capital can build to extraordinary gaps after just a few years of schooling.
As a policy strategy, "resources" are most frequently defined as extra funding. Some policy groups (Center for Educational Policy, www.cep-dc. org; Education Trust, www2.edtrust.org/edtrust), for example, suggest targeted funding based on the number of poor children that have to be educated, in addition to the comparable funding allotments. Surely, additional funding would help to repair the welldocumented inequities in educating middle- and low-income neighborhood children (Carey, 2003). However, additional targeted instructional strategies are needed as well. Placing the most highly trained librarians in high-need areas (instead of the least), for example, is just one type of additional support that has demonstrated impact on children's knowledge gains (Lance, Welborn, \& Hamilton-Pennell, 1993). Using technology to create knowledge-centered environments (Donovan \& Bransford, 2005), presenting children with challenges just manageable enough to maintain engagement, yet not to lead to discouragement, is another type of additional support. Training professionals who may then craft opportunities for intensive engagements with resources (Labbo \& Reinking, 1999; Leu, Kinzer, Coiro, \& Cammack, 2004) is crucial for low-income neighborhood children's further learning. Such targeted instructional strategies, therefore, may include more intensive mentoring, additional adult involvement, more challenging and culturally relevant pedagogy, and learning opportunities associated with quality home environments and mother-child interactions (McGill-Franzen, Lanford, \& Adams, 2002), compressing more experiences and (practice) into the time available.

Serendipitously, we began to discover such targeted intervention through one of our final investigations. Historically, librarians have been caretakers of materials, "apostles of culture" (Garrison, 1979), and in more recent years, information navigators of the Internet and other digitized collections (Jones, Shoemaker, \& Chelton, 2001). Most often, a librarian's educational role has been to serve users by gathering information and providing spaces for learning and reflection. Yet as important as these activities are, McLaughlin and her colleagues (McLaughlin, Irby, \& Langman, 1994), in their study of public institutions in impoverished communities, discovered an additional factor in community-building effortscaring adults that provided stability, consistency, and the ability to go beyond their distinctive job description to take on new roles and responsibilities.

Visiting one of the poorest neighborhood libraries ( $97 \%$ on public assistance), we began to notice a librarian, highly committed to children in the 
neighborhood, taking on a role largely outside the definition of the traditional librarian. Here are some examples from our notes:

Audrey (African American of middle age, librarian for 18 years) greets children by name as they arrive, giving hugs and asking about their day. She takes a few minutes to joke with some 12-year-olds about hairstyles they show her in a magazine. She spends some time showing a special-needs child how to use the computer.

Besides holding three story hours in one day, Audrey walks throughout the children's section constantly. She watches what children are reading and what they are doing on the computer. No wandering is allowed. Children sitting and watching a friend play a game on the computer are admonished, given an age-appropriate book, and told to read. At another point three boys come in, looking for books. Audrey asks one of them what he likes. "Sports," he says. She tells him, "No sports. You've got to find something good to read." She takes him to the shelf with classic books on it. She gives him a book and then requires all of them to write a one-sentence summary of the books they've read (as part of the summer reading program).

She notices two boys playing a science game on the computer. "Do you know how to play it?" she asks. When she doesn't get an answer, she sits down and shows them, playing the game a little and explaining the major points of the program before she lets them take over.

These interactions were far different than those of the traditional librarian (Duran, 1993) behind a desk, who responds to questions and is pleasant but only reactive to requests. Rather, Audrey's activities were highly reminiscent of the kind of mentoring and strategic interactions for selecting materials that were given to children from the middle-class neighborhoods. Deeply committed to the community in which she worked, Audrey (and others like her) went beyond her role description to touch these children's lives (e.g., she started writing clubs and chess clubs, and created a neighborhood directory). In this setting, children received additional supports in the form of more potent, caring, content-driven interactions that significantly affected the amount, type, and quality of reading experiences. These observations, along with others that followed later, have important implications for the training of librarians to work in different community contexts and ongoing professional development. Libraries may wish to consider interventions and trainings that strategically focus on affect and attachment, informal instruction, guidance, and careful monitoring very early on, beginning in preschool, to promote higher quality uses of the library resources.

In sum, national policy in the United States has focused on the achievement gap, the differences in reading scores for middle- and low-income neighbor- hood children. Although this may be related to the achievement gap, we believe that the knowledge gap, representing differentials in information acquired and retained and related to income and social disparities, may be far more important in affecting people's incomes, their social mobility, and ultimately their quality of life. We argue, therefore, that any reform that does not explicitly account for and systematically address early knowledge deficits may be unlikely to compensate for these differences in later years. Continued unabated, this gap between the "information haves" and "information have-nots" could lead to even greater social and economic inequality in our society that will be difficult, if not impossible, to reverse.

SUSAN B. NEUMAN is a professor in educational studies specializing in early literacy development at the University of Michigan. She recently served for two years as the U.S. Assistant Secretary for Elementary and Secondary Education under President George W. Bush. Her research and teaching interests include early literacy for economically disadvantaged children and curriculum. She can be reached at University of Michigan, School of Education, $610 \mathrm{E}$. University Avenue, Ann Arbor, Ml 48109, USA, or by e-mail at sbneuman@umich.edu.

DONNA CELANO is currently an assistant professor of communications at Chestnut Hill College in Philadelphia, Pennsylvania. Previously, she taught at La Salle University and served as Senior Research Associate at Temple University's Department of Curriculum, Instruction, and Technology. Her research and teaching interests include children and media, especially economically disadvantaged children's access to books, computers, and television. She can be reached at Chestnut Hill College, 9601 Germantown Avenue, Philadelphia, PA 19118, USA, or by e-mail at celanod@chc.edu.

\section{REFEREN CES}

ALLINGTON, R. (1983). The reading instruction provided readers of differing reading abilities. Elementary School Journal, 83, 548-559.

ANDERSON, R.C., \& PEARSON, P.D. (1984). A schema-theoretic view of basic processes in reading comprehension. In P.D. Pearson (Ed.), Handbook of reading research (pp. 255-291). New York: Longman. AXELROD, S. (1983). Behavior modification for the classroom teacher. New York: McGraw-Hill.

BALL, S., \& BOGATZ, G. (1970). The first year of Sesame Street: An evaluation. Princeton, NJ: Educational Testing Service.

BARTON, P. (2003). Parsing the achievement gap. Baselines for tracking progress. Princeton, NJ: Educational Testing Service, Policy Information Center.

BEREITER, C., \& ENGELMANN, S. (1966). Teaching disadvantaged children in the preschool. Englewood Cliffs, NJ: Prentice-Hall.

BOGATZ, G.A., \& BALL, S. (1971). The second year of Sesame Street: A continuing evaluation. Princeton, NJ: Educational Testing Service. BRANSFORD, J., BROWN, A., \& COCKING, R. (Eds.). (2000). How people learn. Washington, DC: National Academy Press. BRONFENBRENNER, U. (1979). The ecology of human development. Cambridge, MA: Harvard University Press.

BROWN, M. (1986). Arthur's eyes. New York: Little, Brown.

BRUCE, B., \& HOGAN, M. (1998). The disappearance of technology: Toward an ecological model of literacy. In D. Reinking, M. McKenna, L. Labbo, \& R. Kieffer (Eds.), Handbook of literacy and technology (pp. 269-282). Mahwah, NJ: Erlbaum.

BRYK, A.S., \& RAUDENBUSH, S. (1991). Hierachical linear models for social and behavioural research: Applications and data analysis methods. Newbury Park, CA: Sage. 
BURTLESS, G. (1996). Does money matter?: The effect of school resources on student achievement and adult success. Washington, DC. Brookings Institute Press.

BUS, A., VAN IJZENDOORN, M., \& PELLEGRINI, A. (1995). Joint book reading makes for success in learning to read: A meta-analysis on intergenerational transmission of literacy. Review of Educational Research, 65, 1-21.

CAREY, K. (2003). The funding gap. Washington, DC: Education Trust.

COLEMAN, J., CAMPBELL, E., HOBSON, C., MCPARTLAND, J., MOOD, A. M., WEINFELD, F., ET AL. (1966). Equality of educational opportunity (Vol. 1-2). Washington, DC: U.S. Department of Health, Education, and Welfare, Office of Education.

COMSTOCK, G. (1980). Television in America. Beverly Hills, CA: Sage.

CONNELL, J.P., KUBISCH, A., SCHORR, L., \& WEISS, C. (Eds.). (1995). New approaches to evaluating community initiatives. Washington, DC: Aspen Institute.

COOK, T., APPLETON, H., CONNER, R., SHAFFER, A., TAMKIN, G., \& WEBER, S. (1975). "Sesame Street" revisited. New York: Russell Sage Foundation.

COWAN, K., \& MANASEVIT, L. (2002). The new Title I: Balancing flexibility with accountability. Washington, DC: Thompson.

CROSS, C. (2004). Political education. New York: Teachers College Press.

CUBAN, L. (1986). Teachers and machines: The classroom use of technology since 1920. New York: Teachers College Press.

CUNNINGHAM, A.E., \& STANOVICH, K. (1998). What reading does for the mind. American Educator, 22, 8-15.

DE JONG, M., \& BUS, A. (2004). The efficacy of electronic books in fostering kindergarten children's emergent story understanding. Reading Research Quarterly, 39, 378-393.

DENTON, K., WEST, J., \& WALTSTON, J. (2003). Young children's achievement and classroom experiences: Special analysis on the condition of education. Washington, DC: National Center for Educational Statistics.

DONOVAN, M.S., \& BRANSFORD, J. (2005). How students learn: History, mathematics, and science in the classroom. Washington, DC: National Academy Press.

DRESSMAN, M. (1997). Literacy in the library. Westport, CT: Bergin \& Garvey.

DUNCAN, G., \& BROOKS-GUNN, J. (Eds.). (1997). Consequences of growing up poor. New York: Russell Sage Foundation.

DURAN, C.M. (1993). Gatekeepers in ethnolinguistic communities. Norwood, NJ: Ablex.

FISCHER, C., HOUT, M., JANKOWSKI, M.S., LUCAS, S., SWIDLER, A. \& VOS., K. (1996). Inequality by design: Cracking the bell curve myth. Princeton, NJ: Princeton University Press.

FOSTER, E.M. (2002). How economists think about family resources and child development. Child Development, 73, 1904-1914.

GARRISON, D. (1979). Apostles of culture. New York: Free Press.

GAUL, G. (1997, June 2). Libraries in distress. Philadelphia Inquirer, pp. A1, A20.

GAZIANO, C. (1997). Forecast 2000: Widening knowledge gaps. Journalism and Mass Communications Quarterly, 74, 237-264.

GOETZ, J., \& LECOMPTE, M. (1984). Ethnography and qualitative design in educational research. Orlando, FL: Academic.

HALPERN, R. (1994). Rebuilding the inner city: A history of neighborhood initiatives to address poverty in the U.S. New York: Columbia University Press.

HART, B., \& RISLEY, T. (2003). The early catastrophe. American Educator, 27, 4, 6-9.

HERNSTEIN, R., \& MURRAY, C. (1994). The bell curve. New York, NY: Free Press.

HIMMELWEIT, H., OPPENHEIM, P., \& VINCE, P. (1958). Television and the child. London: Oxford University Press.

HIRSCH, E.D. (1987). Cultural literacy. Boston: Houghton-Mifflin.

HIRSCH, E.D. (2003). Reading comprehension requires knowledge of words and the world. American Educator, 27, 10, 12, 1316-1322, $1328-1329,1348$

HOLLISTER, R., \& HILL, J. (1995). Problems in the evaluation of community-wide initiatives. In J. Connell, A. Kubisch, L. Schorr, \& C. Weiss (Eds.), New approaches to evaluating community initiatives (pp. 127-172). Washington, DC: Aspen Institute.

IMMROTH, B.F., \& LANCE, K. (1996). Output measures for children's services in public libraries: A status report. Public Libraries, 35(4), 240-245.
JONES, P., SHOEMAKER, J., \& CHELTON, M.K. (2001). Do it right! Best practices for serving young adults in school and public libraries. New York: Neal-Schuman.

JUEL, C., GRIFFITH, P.L., \& GOUGH, P. (1986). Acquisition of literacy: A longitudinal study of children in first and second grade. Journal of Educational Psychology, 78, 243-255.

KUBISCH, A., WEISS, C., SCHORR, L., \& CONNELL, J. (Eds.). (1995). Introduction. In J. Connell, A. Kubisch, L. Schorr, \& C. Weiss (Eds.), New approaches to evaluating community initiatives (pp. i-v). Washington, DC: Aspen Institute.

LABBO, L., \& REINKING, D. (1999). Negotiating the multiple realities of technology in literacy research and instruction. Reading Research Quarterly, 34, 478-492.

LANCE, K.C., WELBORN, L., \& HAMILTON-PENNELL, M. (1993). The impact of school library media centers on academic achievement. San Jose, CA: Hi Willow Research and Publishing.

LEE, V., \& BURKAM, D. (2002). Inequality at the starting gate. Washington, DC: Economic Policy Institute.

LEU, D., KINZER, C., COIRO, J., \& CAMMACK, D. (2004). Toward a theory of new literacies emerging from the internet and other information and communication technologies. In R. Ruddell \& N. Unrau (Eds.), Theoretical models and processes of reading (pp. 1570-1612). Newark, DE: International Reading Association.

MACLEOD, J. (1995). Ain't no makin' it. Boulder, CO: Westview Press.

MAYER, S. (1997). What money can't buy. Cambridge, MA: Harvard University Press.

MCGILL-FRANZEN, A., ALLINGTON, R., YOKOI, L., \& BROOKS, G. (1999). Putting books in the classroom seems necessary but not sufficient. Journal of Educational Research, 93(2), 67-74.

MCGILL-FRANZEN, A., LANFORD, C., \& ADAMS, E. (2002). Learning to be literate: A comparison of five urban early childhood programs. Journal of Educational Psychology, 94, 443-464.

MCLANE, J.B., \& MCNAMEE, G. (1990). Early literacy. Cambridge, MA: Harvard University Press.

MCLAUGHLIN, M., IRBY, M., \& LANGMAN, J. (1994). Urban sanctuaries. San Francisco: Jossey-Bass.

MERRIAM, S.B. (1998). Qualitative research and case study applications in education. San Francisco: Jossey-Bass.

MOSTELLER, F., \& MOYNIHAN, D. (1972). A pathbreaking report. In F. Mosteller \& D. Moynihan (Eds.), On equality of educational opportunity (pp. i-iv). New York: Random House.

NATIONAL ASSESSMENT OF EDUCATIONAL PROGRESS (2004). Percentage of students, by reading achievement level, Grade 4. Retrieved June 15, 2005, from http://nces.ed.gov/nationsreportcard/ reading/results2003/natachieve-g4.asp

NEGROPONTE, N. (1996). Being digital. New York: Vintage Press. NEUMAN, S.B. (1995). Literacy in the television age. Norwood, NJ: Ablex.

NEUMAN, S.B. (2001a). Examining the impact of model urban library services for children: A final report to the William Penn Foundation. Philadelphia: Temple University.

NEUMAN, S.B. (2001b). The role of knowledge in early literacy. Reading Research Quarterly, 36, 468-475.

NEUMAN, S.B., \& CELANO, D. (2001). Access to print in middleand low-income communities: An ecological study of four neighborhoods. Reading Research Quarterly, 36, 8-26.

NEUMAN, S.B., CELANO, D., GRECO, A., \& SHUE, P. (2001). Access for all: Closing the book gap for children in early education. Newark, DE: International Reading Association.

REINKING, D., \& ALVERMANN, D. (2005). Editorial: What are evaluation studies, and should they be published in $R R Q$ ? Reading Research Quarterly, 40, 142-146.

ROTHSTEIN, R. (2004). Class and schools. New York, NY: Teachers College Press.

RUMELHART, D.E. (1980). Schemata: The building blocks of cognition. In R.J. Spiro, B.C. Bruce, \& W.F. Brewer (Eds.), Theoretical issues in reading comprehension (pp. 35-58). Hillsdale, NJ: Erlbaum.

SALOMON, G. (1984). Television is "easy" and print is "tough": The differential investment of mental effort as a function of perceptions and attributions. Journal of Educational Psychology, 76, 647-658.

SCHRAMM, W., LYLE, J., \& PARKER, E. (1961). Television and the lives of our children. Stanford, CA: Stanford University Press.

STANOVICH, K.E. (1986). Matthew effects in reading: Some consequences of individual differences in the acquisition of literacy. Reading Research Quarterly, 21, 360-406. 
STANOVICH, K.E., \& CUNNINGHAM, A. (1993). Where does knowledge come from? Specific associations between print exposure and information acquisition. Journal of Educational Psychology, 85, 211-229.

STANOVICH, K.E., WEST, R., \& HARRISON, M. (1995). Knowledge growth and maintenance across the life span: The role of print exposure. Journal of Educational Psychology, 31, 811-826.

TEALE, W., \& SULZBY, E. (Eds.). (1986). Emergent literacy: Writing and reading. Norwood, NJ: Ablex.

THARP, R., \& GALLIMORE, R. (1988). Rousing minds to life. Cambridge, England: Cambridge University Press.

TICHENOR, P.J., DONOHUE, G., \& OLIEN, C. (1970). Mass media flow and differential growth in knowledge. Public Opinion Quarterly, 34, 159-170.

VAN HOUSE, N. (1983). Public library user fees. Westport, CT: Greenwood Press.

VAN SLYCK, A. (1995). Free to all. Chicago: University of Chicago Press.

VISWANATH, K., \& FINNEGAN, J. (1996). The knowledge gap hypothesis: Twenty-five years later. In B.R. Burleson (Ed.), Communication yearbook: Volume 19 (pp. 187-227). Newbury Park, CA: Sage.
WALBERG, H., \& TSAI, S. (1983). Matthew effects in education. American Educational Research Journal, 20, 359-373.

WANG, M., HAERTEL, E., \& WALBERG, H. (1993). Toward a knowledge base for school learning. Review of Educational Research, 63, 249-294.

WEISS, C. (1995). Nothing as practical as good theory: Exploring theory-based evaluation for comprehensive community initiatives for children and families. In J. Connell, A. Kubisch, L. Schorr, \& C. Weiss (Eds.), New approaches to evaluating community initiatives (pp. 65-92). Washington, DC: Aspen Institute.

WELCH, F. (2001). The causes and consequences of increasing inequality. Chicago: University of Chicago Press.

WELLS, G. (1985). The meaning makers. Portsmouth, NH: Heinemann

WILSON, W.J. (1987). The truly disadvantaged. Chicago: University of Chicago Press.

Received November 23, 2004

Final revision received May 24, 2005

Accepted July 6, 2005 